\title{
Macro-Average: Rare Types Are Important Too
}

\author{
Thamme Gowda \\ Information Sciences Institute \\ University of Southern California \\ tg@isi.edu \\ Constantine Lignos \\ Michtom School of Computer Science \\ Brandeis University \\ lignos@brandeis.edu
}

\begin{abstract}
While traditional corpus-level evaluation metrics for machine translation (MT) correlate well with fluency, they struggle to reflect adequacy. Model-based MT metrics trained on segment-level human judgments have emerged as an attractive replacement due to strong correlation results. These models, however, require potentially expensive re-training for new domains and languages. Furthermore, their decisions are inherently non-transparent and appear to reflect unwelcome biases. We explore the simple type-based classifier metric, MACROF $_{1}$, and study its applicability to MT evaluation. We find that $\mathrm{MACROF}_{1}$ is competitive on direct assessment, and outperforms others in indicating downstream cross-lingual information retrieval task performance. Further, we show that $\mathrm{MACROF}_{1}$ can be used to effectively compare supervised and unsupervised neural machine translation, and reveal significant qualitative differences in the methods' outputs. ${ }^{1}$
\end{abstract}

\section{Introduction}

Model-based metrics for evaluating machine translation such as BLEURT (Sellam et al., 2020), ESIM (Mathur et al., 2019), and YiSi (Lo, 2019) have recently attracted attention due to their superior correlation with human judgments (Ma et al., 2019). However, BLEU (Papineni et al., 2002) remains the most widely used corpus-level MT metric. It correlates reasonably well with human judgments, and moreover is easy to understand and cheap to calculate, requiring only reference translations in the target language. By contrast, model-based metrics require tuning on thousands of examples of human evaluation for every new target language or domain

\footnotetext{
${ }^{1}$ Tools and analysis are available at https://github. com/thammegowda/007 - mt - eval - macro. MT evaluation metrics are at https://github.com/isi-nlp/sacrebleu/tree/ macroavg-naacl21.
}

Weiqiu You

Dept of Computer and Information Science
University of Pennsylvania
weiqiuy@seas . upenn.edu

\author{
Jonathan May \\ Information Sciences Institute \\ University of Southern California \\ jonmay@isi.edu
}

(Sellam et al., 2020). Model-based metric scores are also opaque and can hide undesirable biases, as can be seen in Table 1 .

\begin{tabular}{lll} 
Reference: & \multicolumn{2}{l}{ You must be a doctor. } \\
Hypothesis: & \multicolumn{2}{c}{ must be a doctor. } \\
& He & -0.735 \\
& Joe & -0.975 \\
& Sue & -1.043 \\
& She & -1.100 \\
\hline Reference: & It is the greatest country in the world. \\
Hypothesis: & & is the greatest country in the world. \\
& France & -0.022 \\
& America & -0.060 \\
& Russia & -0.161 \\
& Canada & -0.309
\end{tabular}

Table 1: A demonstration of BLEURT's internal biases; model-free metrics like BLEU would consider each of the errors above to be equally wrong.

The source of model-based metrics' (e.g. BLEURT) correlative superiority over model-free metrics (e.g. BLEU) appears to be the former's ability to focus evaluation on adequacy, while the latter are overly focused on fluency. BLEU and most other generation metrics consider each output token equally. Since natural language is dominated by a few high-count types, an MT model that concentrates on getting its if s, ands and buts right will benefit from BLEU in the long run more than one that gets its xylophones, peripatetics, and defenestrates right. Can we derive a metric with the discriminating power of BLEURT that does not share its bias or expense and is as interpretable as BLEU?

As it turns out, the metric may already exist and be in common use. Information extraction and other areas concerned with classification have long used both micro averaging, which treats each token equally, and macro averaging, which instead treats each type equally, when evaluating. The latter in particular is useful when seeking to avoid results dominated by overly frequent types. In this 
work we take a classification-based approach to evaluating machine translation in order to obtain an easy-to-calculate metric that focuses on adequacy as much as BLEURT but does not have the expensive overhead, opacity, or bias of model-based methods.

Our contributions are as follows: We consider MT as a classification task, and thus admit MACROF $_{1}$ as a legitimate approach to evaluation (Section 2). We show that $\mathrm{MACROF}_{1}$ is competitive with other popular methods at tracking human judgments in translation (Section 3.2). We offer an additional justification of $\mathrm{MACROF}_{1}$ as a performance indicator on adequacy-focused downstream tasks such as cross-lingual information retrieval (Section 3.3). Finally, we demonstrate that MACROF $_{1}$ is just as good as the expensive BLEURT at discriminating between structurally different MT approaches in a way BLEU cannot, especially regarding the adequacy of generated text, and provide a novel approach to qualitative analysis of the effect of metrics choice on quantitative evaluation (Section 4).

\section{NMT as Classification}

Neural machine translation (NMT) models are often viewed as pairs of encoder-decoder networks. Viewing NMT as such is useful in practice for implementation; however, such a view is inadequate for theoretical analysis. Gowda and May (2020) provide a high-level view of NMT as two fundamental ML components: an autoregressor and a classifier. Specifically, NMT is viewed as a multi-class classifier that operates on representations from an autoregressor. We may thus consider classifier-based evaluation metrics.

Consider a test corpus, $T=\left\{\left(x^{(i)}, h^{(i)}, y^{(i)}\right) \mid i=\right.$ $1,2,3 \ldots m\}$ where $x^{(i)}, h^{(i)}$, and $y^{(i)}$ are source, system hypothesis, and reference translation, respectively. Let $x=\left\{x^{(i)} \forall i\right\}$ and similar for $h$ and $y$. Let $V_{h}, V_{y}, V_{h \cap y}$, and $V$ be the vocabulary of $h$, the vocabulary of $y, V_{h} \cap V_{y}$, and $V_{h} \cup V_{y}$, respectively. For each class $c \in V$,

$$
\begin{aligned}
\operatorname{Preds}(c) & =\sum_{i=1}^{m} C\left(c, h^{(i)}\right) \\
\operatorname{Refs}(c) & =\sum_{i=1}^{m} C\left(c, y^{(i)}\right) \\
\operatorname{MATCH}(c) & =\sum_{i=1}^{m} \min \left\{C\left(c, h^{(i)}\right), C\left(c, y^{(i)}\right)\right\}
\end{aligned}
$$

where $C(c, a)$ counts the number of tokens of type $c$ in sequence $a$ (Papineni et al., 2002). For each class $c \in V_{h \cap y}$, precision $\left(P_{c}\right)$, recall $\left(R_{c}\right)$, and $F_{\beta}$ measure $\left(F_{\beta ; c}\right)$ are computed as follows: ${ }^{2}$

$$
\begin{aligned}
P_{c} & =\frac{\operatorname{MATCH}(c)}{\operatorname{PREDS}(c)} ; \quad R_{c}=\frac{\operatorname{MATCH}(c)}{\operatorname{REFS}(c)} \\
F_{\beta ; c} & =\left(1+\beta^{2}\right) \frac{P_{c} \times R_{c}}{\beta^{2} \times P_{c}+R_{c}}
\end{aligned}
$$

The macro-average consolidates individual performance by averaging by type, while the microaverage averages by token:

$$
\begin{aligned}
\operatorname{MACROF}_{\beta} & =\frac{\sum_{c \in V} F_{\beta ; c}}{|V|} \\
\operatorname{MICROF}_{\beta} & =\frac{\sum_{c \in V} f(c) \times F_{\beta ; c}}{\sum_{c^{\prime} \in V} f\left(c^{\prime}\right)}
\end{aligned}
$$

where $f(c)=\operatorname{REFS}(c)+k$ for smoothing factor $k .^{3}$ We scale $\mathrm{MACROF}_{\beta}$ and $\mathrm{MICROF}_{\beta}$ values to percentile, similar to BLEU, for the sake of easier readability.

\section{Justification for MACROF M $_{1}$}

In the following sections, we verify and justify the utility of $\mathrm{MACROF}_{1}$ while also offering a comparison with popular alternatives such as $\mathrm{MICROF}_{1}$, BLEU, CHRF ${ }_{1}$, and BLEURT. ${ }^{4}$ We use Kendall's rank correlation coefficient, $\tau$, to compute the association between metrics and human judgments. Correlations with p-values smaller than $\alpha=0.05$ are considered to be statistically significant.

\subsection{Data-to-Text: WebNLG}

We use the 2017 WebNLG Challenge dataset (Gardent et al., 2017; Shimorina, 2018) ${ }^{5}$ to analyze the differences between micro- and macro- averaging. WebNLG is a task of generating English text for sets of triples extracted from DBPedia. Human annotations are available for a sample of 223 records each from nine NLG systems. The human

\footnotetext{
${ }^{2}$ We consider $F_{\beta ; c}$ for $c \notin V_{h \cap y}$ to be 0 .

${ }^{3}$ We use $k=1$. When $k \rightarrow \infty, \mathrm{MICROF}_{\beta} \rightarrow \mathrm{MACROF}_{\beta}$

${ }^{4} \mathrm{BLEU}$ and $\mathrm{CHRF}_{1}$ scores reported in this work are computed with SACREBLEU; see the Appendix for details. BLEURT scores are from the base model (Sellam et al., 2020). We consider two varieties of averaging to obtain a corpus-level metric from the segment-level BLEURT: mean and median of segment-level scores per corpus.

${ }^{5}$ https://gitlab.com/webnlg/ webnlg-human-evaluation
} 


\begin{tabular}{lrr} 
Name & Fluency \& Grammar & Semantics \\
\hline \hline BLEU & $\times .444$ & $\times .500$ \\
CHRF $_{1}$ & $\times .278$ & .778 \\
MACROF $_{1}$ & $\times .222$ & .722 \\
MICROF $_{1}$ & $\times .333$ & .611 \\
\hline BLEURTmean & $\times .444$ & .833 \\
BLEURTmedian & .611 & .667
\end{tabular}

Table 2: WebNLG data-to-text task: Kendall's $\tau$ between system-level MT metric scores and human judgments. Fluency and grammar are correlated identically by all metrics. Values that are not significant at $\alpha=0.05$ are indicated by ${ }^{\times}$.

judgments provided have three linguistic aspectsfluency, grammar, and semantics ${ }^{6}$ - which enable us to perform a fine grained analysis of our metrics. We compute Kendall's $\tau$ between metrics and human judgments, which are reported in Table 2.

As seen in Table 2, the metrics exhibit much variance in agreements with human judgments. For instance, BLEURTmedian is the best indicator of fluency and grammar, however BLEURTmean is best on semantics. BLEURT, being a model-based measure that is directly trained on human judgments, scores relatively higher than others. Considering the model-free metrics, $\mathrm{CHRF}_{1}$ does well on semantics but poorly on fluency and grammar compared to BLEU. Not surprisingly, both MICROF $_{1}$ and $\mathrm{MACROF}_{1}$, which rely solely on unigrams, are poor indicators of fluency and grammar compared to BLEU, however MACROF $\mathrm{F}_{1}$ is clearly a better indicator of semantics than BLEU. The discrepancy between MICROF $_{1}$ and $\mathrm{MACROF}_{1}$ regarding their agreement with fluency, grammar, and semantics is expected: micro-averaging pays more attention to function words (as they are frequent types) that contribute to fluency and grammar whereas macroaveraging pays relatively more attention to the content words that contribute to semantic adequacy.

The take away from this analysis is as follows: $\mathrm{MACROF}_{1}$ is a strong indicator of semantic adequacy, however, it is a poor indicator of fluency. We recommend using either $\mathrm{MACROF}_{1}$ or $\mathrm{CHRF}_{1}$ when semantic adequacy and not fluency is a desired goal.

\subsection{Machine Translation: WMT Metrics}

In this section, we verify how well the metrics agree with human judgments using Workshop on Machine Translation (WMT) metrics task datasets for 2017-2019 (Bojar et al., 2017; Ma et al., 2018,

\footnotetext{
${ }^{6}$ Fluency and grammar, which are elicited with nearly identical directions (Gardent et al., 2017), are identically correlated.
}

2019). ${ }^{7}$ We first compute scores from each MT metric, and then calculate the correlation $\tau$ with human judgments.

As there are many language pairs and translation directions in each year, we report only the mean and median of $\tau$, and number of wins per metric for each year in Table 3. We have excluded BLEURT from comparison in this section since the BLEURT models are fine-tuned on the same datasets on which we are evaluating the other methods. ${ }^{8} \mathrm{CHRF}_{1}$ has the strongest mean and median agreement with human judgments across the years. In 2018 and 2019, both MACROF 1 and MICROF 1 mean and median agreements outperform BLEU whereas in 2017 BLEU was better than MACROF $_{1}$ and MICROF $_{1}$.

As seen in Section 3.1, MACROF $_{1}$ weighs towards semantics whereas $\mathrm{MICROF}_{1}$ and BLEU weigh towards fluency and grammar. This indicates that recent MT systems are mostly fluent, and adequacy is the key discriminating factor amongst them. BLEU served well in the early era of statistical MT when fluency was a harder objective. Recent advancements in neural MT models such as Transformers (Vaswani et al., 2017) produce fluent outputs, and have brought us to an era where semantic adequacy is the focus.

\subsection{Cross-Lingual Information Retrieval}

In this section, we determine correlation between MT metrics and downstream cross-lingual information retrieval (CLIR) tasks. CLIR is a kind of information retrieval (IR) task in which documents in one language are retrieved given queries in another (Grefenstette, 2012). A practical solution to CLIR is to translate source documents into the query language using an MT model, then use a monolingual IR system to match queries with translated documents. Correlation between MT and IR metrics is accomplished in the following steps:

1. Build a set of MT models and measure their performance using MT metrics.

2. Using each MT model in the set, translate all source documents to the target language, build an IR model, and measure IR performance on translated documents.

3. For each MT metric, find the correlation between the set of MT scores and their corresponding set of IR scores. The MT metric that has a

\footnotetext{
${ }^{7}$ http : //wWw. statmt. org/wmt19/metrics - task.html

${ }^{8}$ https://github.com/google-research/bleurt
} 


\begin{tabular}{rrlrrrrr} 
Year & Pairs & & $\star$ BLEU & BLEU & MACROF $_{1}$ & MICROF $_{1}$ & CHRF $_{1}$ \\
\hline \hline \multirow{2}{*}{2019} & \multirow{2}{*}{18} & Mean & .751 & .771 & .821 & .818 & .841 \\
& & Median & .782 & .752 & .844 & .844 & .875 \\
& & Wins & 3 & 3 & $\mathbf{6}$ & 3 & 5 \\
\hline \multirow{2}{*}{2018} & \multirow{2}{*}{14} & Mean & .858 & .857 & .875 & .873 & .902 \\
& & Median & .868 & .868 & .901 & .879 & .919 \\
& & Wins & 1 & 2 & 3 & 2 & $\mathbf{6}$ \\
\hline \multirow{2}{*}{2017} & \multirow{2}{*}{13} & Mean & .752 & .713 & .714 & .742 & .804 \\
& & Median & .758 & .733 & .735 & .728 & .791 \\
& & Wins & 5 & 4 & 2 & 2 & $\mathbf{6}$
\end{tabular}

Table 3: WMT 2017-19 Metrics task: Mean and median Kendall's $\tau$ between MT metrics and human judgments. Correlations that are not significant at $\alpha=0.05$ are excluded from the calculation of mean, and median, and wins. See Appendix Tables 9, 10, and 11 for full details. $\star$ BLEU is pre-computed scores available in the metrics packages. In 2018 and 2019, both MACROF $_{1}$ and MICROF $_{1}$ outperform BLEU, MACROF 1 outperforms MICROF . CHRF $_{1}$ has strongest mean and median agreements across the years. Judging based on the number of wins, MACROF $_{1}$ has steady progress over the years, and outperforms others in 2019.

stronger correlation with the IR metric(s) is more useful than the ones with weaker correlations.

4. Repeat the above steps on many languages to verify the generalizability of findings.

An essential resource of this analysis is a dataset with human annotations for computing MT and IR performances. We conduct experiments on two datasets: firstly, on data from the 2020 workshop on Cross-Language Search and Summarization of Text and Speech (CLSSTS) (Zavorin et al., 2020), and secondly, on data originally from Europarl, prepared by Lignos et al. (2019) (Europarl).

\subsubsection{CLSSTS Datasets}

CLSSTS datasets contain queries in English (EN), and documents in many source languages along with their human translations, as well as querydocument relevance judgments. We use three source languages: Lithuanian (LT), Pashto (PS), and Bulgarian (BG). The performance of this CLIR task is evaluated using two IR measures: Actual Query Weighted Value (AQWV) and Mean Average Precision (MAP). AQWV ${ }^{9}$ is derived from Actual Term Weighted Value (ATWV) metric (Wegmann et al., 2013).

We use a single CLIR system (Boschee et al., 2019) with the same IR settings for all MT models in the set, and measure Kendall's $\tau$ between MT and IR measures. The results, in Table 4, show that MACROF $_{1}$ is the strongest indicator of CLIR downstream task performance in five out of six settings. AQWV and MAP have a similar trend in agreement to the MT metrics. CHRF $F_{1}$ and BLEURT, which are strong contenders when generated text is directly evaluated by humans, do not indicate

\footnotetext{
${ }^{9}$ https://www.nist.gov/system/files/documents/2017/10/26/aqwv_derivation.pdf
}

CLIR task performance as well as $\mathrm{MACROF}_{1}$, as CLIR tasks require faithful meaning equivalence across the language boundary, and human translators can mistake fluent output for proper translations (Callison-Burch et al., 2007).

\subsubsection{Europarl Datasets}

We perform a similar analysis to Section 3.3.1 but on another cross-lingual task set up by Lignos et al. (2019) for Czech $\rightarrow$ English (CS-EN) and German $\rightarrow$ English (DE-EN), using publicly available data from the Europarl v7 corpus (Koehn, 2005). This task differs from the CLSSTS task (Section 3.3.1) in several ways. Firstly, MT metrics are computed on test sets from the news domain, whereas IR metrics are from the Europarl domain. The domains are thus intentionally mismatched between MT and IR tests. Secondly, since there are no queries specifically created for the Europarl domain, GOV2 TREC topics 701-850 are used as domain-relevant English queries. And lastly, since there are no query-document relevance human judgments for the chosen query and document sets, the documents retrieved by BM25 (Jones et al., 2000) on the English set for each query are treated as relevant documents for computing the performance of the CS-EN and DE-EN CLIR setup. As a result, IR metrics that rely on boolean query-document relevance judgments as ground truth are less informative, and we use Rank-Based Overlap (RBO; $p=0.98$ ) (Webber et al., 2010) as our IR metric.

We perform our analysis on the same experiments as Lignos et al. (2019). ${ }^{10}$ NMT models for CS-EN and DE-EN translation are trained using a convolutional NMT architecture (Gehring

\footnotetext{
${ }^{10}$ https://github. com/ConstantineLignos/ mt-clir-emnlp- 2019
} 


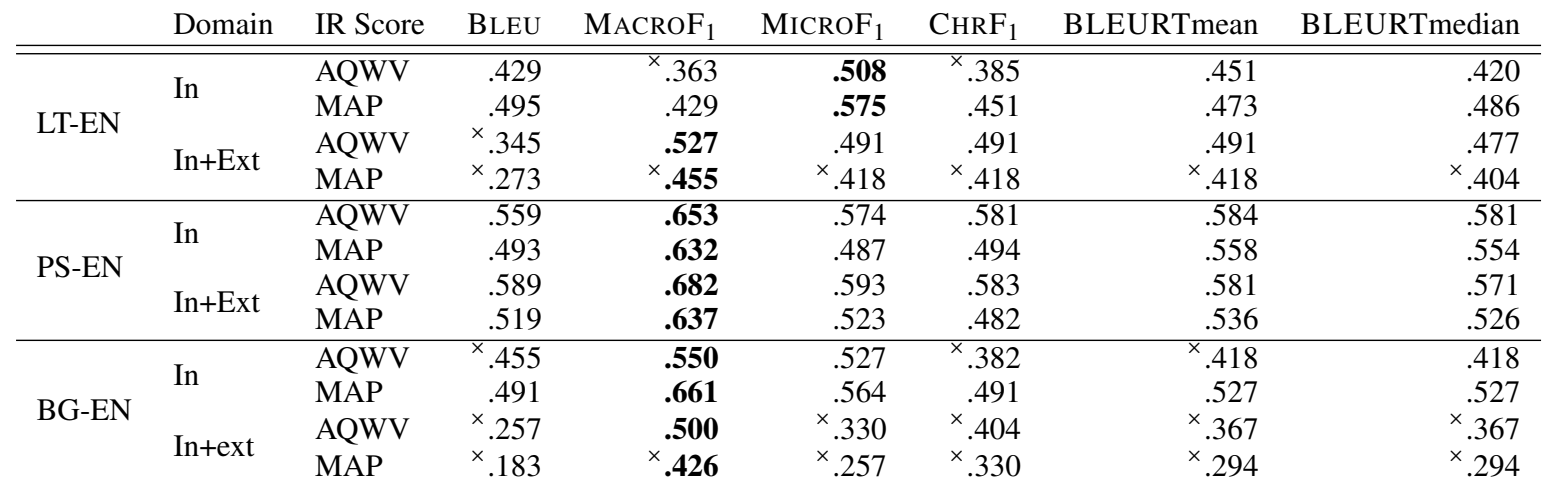

Table 4: CLSSTS CLIR task: Kendall's $\tau$ between IR and MT metrics under study. The rows with Domain=In are where MT and IR scores are computed on the same set of documents, whereas Domain=In+Ext are where IR scores are computed on a larger set of documents that is a superset of segments on which MT scores are computed. Bold values are the best correlations achieved in a row-wise setting; values with ${ }^{\times}$are not significant at $\alpha=0.05$.

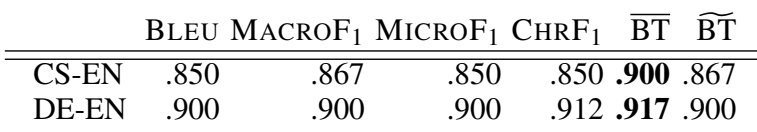

Table 5: Europarl CLIR task: Kendall's $\tau$ between MT metrics and RBO. $\overline{\mathrm{BT}}$ and $\widetilde{\mathrm{BT}}$ are short for BLEURTmean and BLEURTmedian. All correlations are significant at $\alpha=0.05$.

et al., 2017) implemented in the FAIRSeq (Ott et al., 2019) toolkit. For each of CS-EN and DE-EN, a total of 16 NMT models that are based on different quantities of training data and BPE hyperparameter values are used. The results in Table 5 show that BLEURT has the highest correlation in both cases. Apart from the trained BLEURTmedian metric, MACROF $_{1}$ scores higher than the others on CS-EN, and is competitive on CS-EN. MACROF 1 is not the metric with highest IR task correlation in this setting, unlike in Section 3.3.1, however it is competitive with BLEU and $\mathrm{CHRF}_{1}$, and thus a safe choice as a downstream task performance indicator.

\section{Spotting Qualitative Differences Between Supervised and Unsupervised NMT with MACROF M $_{1}$}

Unsupervised neural machine translation (UNMT) systems trained on massive monolingual data without parallel corpora have made significant progress recently (Artetxe et al., 2018; Lample et al., 2018a,b; Conneau and Lample, 2019; Song et al., 2019; Liu et al., 2020). In some cases, UNMT yields a BLEU score that is comparable with strong ${ }^{11}$ supervised neural machine transla-

\footnotetext{
${ }^{11}$ though not, generally, the strongest
}

tion (SNMT) systems. In this section we leverage $\mathrm{MACROF}_{1}$ to investigate differences in the translations from UNMT and SNMT systems that have similar BLEU.

We compare UNMT and SNMT for English $\leftrightarrow$ German (EN-DE, DE-EN), English $\leftrightarrow$ French (ENFR, FR-EN), and English $\leftrightarrow$ Romanian (EN-RO, RO-EN). All our UNMT models are based on XLM (Conneau and Lample, 2019), pretrained by Yang (2020). We choose SNMT models with similar BLEU on common test sets by either selecting from systems submitted to previous WMT News Translation shared tasks (Bojar et al., 2014, 2016) or by building such systems. ${ }^{12}$ Specific SNMT models chosen are in the Appendix (Table 12).

Table 6 shows performance for these three language pairs using a variety of metrics. Despite comparable scores in BLEU and only minor differences in MICROF $F_{1}$ and $\mathrm{CHRF}_{1}$, SNMT models have consistently higher $\mathrm{MACROF}_{1}$ and BLEURT than the UNMT models for all six translation directions.

In the following section, we use a pairwise maximum difference discriminator approach to compare corpus-level metrics BLEU and $\mathrm{MACROF}_{1}$ on a segment level. Qualitatively, we take a closer look at the behavior of the two metrics when comparing a translation with altered meaning to a translation with differing word choices using the metric.

\footnotetext{
${ }^{12}$ We were unable to find EN-DE and DE-EN systems with comparable BLEU in WMT submissions so we built standard Transformer-base (Vaswani et al., 2017) models for these using appropriate quantity of training data to reach the desired BLEU performance. We report EN-RO results with diacritic removed to match the output of UNMT.
} 


\begin{tabular}{|c|c|c|c|c|c|c|c|c|c|c|c|c|c|c|c|c|c|c|}
\hline & \multicolumn{3}{|c|}{ BLEU } & \multicolumn{3}{|c|}{ MACROF $_{1}$} & \multicolumn{3}{|c|}{ MICROF $_{1}$} & \multicolumn{3}{|c|}{$\mathrm{CHRF}_{1}$} & \multicolumn{3}{|c|}{ BLEURTmean } & \multicolumn{3}{|c|}{ BLEURTmedian } \\
\hline & SN & UN & $\Delta$ & SN & UN & $\Delta$ & SN & UN & $\Delta$ & SN & UN & $\Delta$ & SN & UN & $\Delta$ & SN & UN & \\
\hline DE-EN & 2.7 & 33.9 & 1.2 & .5 & 3.6 & 4.9 & 3.7 & 57.9 & 0.8 & 9.9 & 58.0 & 1.9 & 211 & -.026 & .24 & .285 & .067 & .22 \\
\hline & 4.0 & 24.0 & 0.0 & 4.0 & 3.5 & 0.5 & 7.7 & 48.1 & -0.4 & 3.3 & 52.0 & 1.3 & 34 & -.204 & .07 & -.112 & .19 & .09 \\
\hline & 31.1 & 31.2 & -0.1 & & 3.6 & 8.0 & 60.5 & 58.3 & 2.2 & .1 & 57.3 & 1.8 & .182 & .066 & .17 & 243 & .154 & .09 \\
\hline & 25.6 & 27.1 & -1.5 & 31 & 7.3 & 4.6 & .0 & 52.3 & 0.7 & .0 & 57.7 & -1.7 & 04 & .042 & .06 & 096 & .063 & .03 \\
\hline & 30.8 & 29.6 & 1.2 & 40.3 & 33.0 & 7.3 & 59.8 & 56.5 & 3.3 & & 54.7 & 3. & .004 & -.058 & .06 & .045 & .004 & .04 \\
\hline EN-RO & 1.2 & 31.0 & 0.2 & 34.6 & 31.0 & 3.6 & 55.4 & 53.4 & 2.0 & 59.3 & 56.7 & 2.6 & .030 & -.046 & .08 & .027 & -.038 & .07 \\
\hline
\end{tabular}

Table 6: For each language direction, UNMT (UN) models have similar BLEU to SNMT (SN) models, and $\mathrm{CHRF}_{1}$ and $\mathrm{MICROF}_{1}$ have small differences. However, $\mathrm{MACROF}_{1}$ scores differ significantly, consistently in favor of SNMT. Both corpus-level interpretations of BLEURT support the trend reflected by $\mathrm{MACROF}_{1}$, but the value differences are difficult to interpret.

\begin{tabular}{|c|c|c|c|c|c|}
\hline$\delta_{\mathrm{MACROF}_{1}}$ & Fav & Analysis & $\delta_{\mathrm{BLEU}}$ & Fav & Analysis \\
\hline .071 & $\mathrm{~S}$ & S: synonym; U: untranslation, noun & .048 & $\mathrm{~S}$ & $\begin{array}{l}\text { S: word order; U: word order, untranslation, } \\
\text { ending }\end{array}$ \\
\hline .064 & $S$ & S: synonym; U: untranslation & .046 & $S$ & $\begin{array}{l}\text { S: spelling variation; U: synonym, word order, } \\
\text { punctuation }\end{array}$ \\
\hline-.055 & $\mathrm{U}$ & U: no issues; S: untranslation & .044 & $S$ & $\begin{array}{l}\text { S: extra determiner; U: paraphrase, synonym, } \\
\text { number, untranslation }\end{array}$ \\
\hline .052 & $S$ & S: synonym; U: untranslation, noun & .042 & $S$ & $\begin{array}{l}\text { S: synonym; U: synonym, punctuation, extra } \\
\text { adverb }\end{array}$ \\
\hline-.045 & $\mathrm{U}$ & U: no issues; S: untranslation & -.039 & $\mathrm{U}$ & $\mathrm{U}:$ no issues; $\mathrm{S}:$ noun, verb \\
\hline .044 & $S$ & $\begin{array}{l}\text { S: synonym, word order; U: subject, trunca- } \\
\text { tion, word order }\end{array}$ & -.037 & $\mathrm{U}$ & $\mathrm{U}$ : no issues; $\mathrm{S}$ : punctuation \\
\hline .044 & S & se. U. untranslation & -.034 & $\mathrm{U}$ & $\mathrm{U}: \mathrm{n}$ \\
\hline .043 & $S$ & S: inflection, word order; $\mathrm{U}$ : number & -.032 & $\mathrm{U}$ & $\mathrm{U}$ : no issues; $\mathrm{S}$ : adjective, noun \\
\hline-.041 & $\mathrm{U}$ & $\begin{array}{l}\mathrm{U} \text { : adjective, verb; S: omitted verb, untransla- } \\
\text { tion }\end{array}$ & -.032 & $\mathrm{U}$ & $\begin{array}{l}\mathrm{U}: \text { untranslation; S: tense, word order, mean- } \\
\text { ing, active/passive voice }\end{array}$ \\
\hline .041 & $S$ & S: time, word order; U: time, nouns & -.031 & $\mathrm{U}$ & $\begin{array}{l}\text { U: untranslation; S: word order, synonym, ex- } \\
\text { tra_conj }\end{array}$ \\
\hline
\end{tabular}

Table 7: Analysis of the ten DE-EN test set segments with the most favoritism in SNMT (S) or UNMT (U), according to MACROF 1 (left) and BLEU (right). Fav is the favored system by metrics. The complete text of the sentences is in the Appendix, Tables 15 and 16.

\subsection{Pairwise Maximum Difference Discriminator}

We consider cases where a metric has a strong opinion of one translation system over another, and analyze whether the opinion is well justified. In order to obtain this analysis, we employ a pairwise segment-level discriminator from within a corpuslevel metric, which we call favoritism.

We extend the definition of $T$ from Section 2 to $T=\left\{x, h_{S}, h_{U}, y\right\}$ where each of $h_{S}$ and $h_{U}$ is a separate system's hypothesis set for $x .{ }^{13}$ Let $M$ be a corpus-level measure such that $M(h, y) \in \mathbb{R}$ and a higher value implies better translation quality. $M\left(h^{(-i)}, y^{(-i)}\right)$ is the corpus-level score obtained by excluding $h^{(i)}$ and $y^{(i)}$ from $h$ and $y$, respectively. We define the benefit of segment $i, \delta_{M}(i ; h)$ :

$$
\delta_{M}(i ; h)=M(h, y)-M\left(h^{(-i)}, y^{(-i)}\right)
$$

If $\delta_{M}(i ; h)>0$, then $i$ is beneficial to $h$ with respect to $M$, as the inclusion of $h^{(i)}$ increases the corpus-

\footnotetext{
${ }^{13}$ The subscripts represent SNMT and UNMT in this case, though the definition is general.
}

level score. We define the favoritism of $M$ toward $i$ as $\delta_{M}\left(i ; h_{S}, h_{U}\right)$ :

$$
\delta_{M}\left(i ; h_{S}, h_{U}\right)=\delta_{M}\left(i ; h_{S}\right)-\delta_{M}\left(i ; h_{U}\right)
$$

If $\delta_{M}\left(i ; h_{S}, h_{U}\right)>0$ then $M$ favors the translation of $x^{(i)}$ by system $S$ over that in system $U$.

Table 7 reflects the results of a manual examination of the ten sentences in the DE-EN test set with greatest magnitude favoritism; complete results are in the Appendix, Tables 15 and 16. Meaningaltering changes such as 'untranslation', (wrong) 'time', and (wrong) 'translation' are marked in italics, while changes that do not fundamentally alter the meaning, such as 'synonym,' (different) 'inflection,' and (different) 'word order' are marked in plain text. ${ }^{14}$

The results indicate that $\mathrm{MACROF}_{1}$ generally favors SNMT, and with good reasons, as the favored translation does not generally alter sentence meaning, while the disfavored translation does. On

\footnotetext{
${ }^{14}$ Some changes, such as 'word order' may change meaning; these are italicized or not on a case-by-case basis.
} 


\begin{tabular}{|c|c|}
\hline $6^{\text {th }}$ & $\delta_{\mathrm{MACROF} 1}\left(i, h_{S}, h_{U}\right): .044, \delta_{\mathrm{BLEU}}\left(i, h_{S}, h_{U}\right):-.00087, \delta_{\text {BLEURT }}\left(i, h_{S}, h_{U}\right): .97$ \\
\hline \multirow[t]{3}{*}{ Ref } & Ever since I joined Labour 32 years ago as a school pupil, provoked by the Thatcher government's neglect that had left my \\
\hline & comprehensive school classroom literally falling down, I've sought to champion better public services for those who need them most \\
\hline & - whether as a local councillor or government minister. \\
\hline \multirow[t]{2}{*}{ SNMT } & 32 years ago, I joined Labour as a student because of the neglect of the Thatcher government, which had led to my classroom literally \\
\hline & collapsed, and as a result I tried to promote better public services for those who need it most, whether as a local council or ministers. \\
\hline UNMT & Last 32 years ago, as a student, because of the disdain for the Thatcher-era government, Labour joined Labour. \\
\hline Problems & IT: synonym, word_order UNMT: subject, truncation, word_order \\
\hline
\end{tabular}

Table 8: An example of favoritism that illustrates the differences between MACROF 1 and BLEU. Translations of the DE-EN test sentence with sixth largest magnitude favoritism according to MACROF $_{1}$, along with the favoritism according to BLEU (not in the top ten). UNMT's translation does not include the second half of the sentence. MACROF $_{1}$ favors SNMT, but BLEU favors UNMT.

the other hand, for the ten most favored sentences according to BLEU, four do not contain meaningaltering divergences in the disfavored translation. Importantly, none of the sentences with greatest favoritism according to $\mathrm{MACROF}_{1}$, all of which having meaning altering changes in the disfavored alternatives, appears in the list for BLEU. This indicates relatively bad judgment on the part of BLEU. One case of good judgment from $\mathrm{MACROF}_{1}$ and bad judgment from BLEU regarding truncation is shown in Table 8.

From our qualitative examinations, MACROF $_{1}$ is better than BLEU at discriminating against untranslations and trucations in UNMT. The case is similar for FR-EN and RO-EN, except that ROEN has more untranslations for both SNMT and UNMT, possibly due to the smaller training data. Complete tables and annotated sentences are in the Appendix, in Section C.

\section{Related Work}

\subsection{MT Metrics}

Many metrics have been proposed for MT evaluation, which we broadly categorize into modelfree or model-based. Model-free metrics compute scores based on translations but have no significant parameters or hyperparameters that must be tuned $a$ priori; these include BLEU (Papineni et al., 2002), NIST (Doddington, 2002), TER (Snover et al., 2006), and CHRF $_{1}$ (Popović, 2015). Modelbased metrics have a significant number of parameters and, sometimes, external resources that must be set prior to use. These include METEOR (Banerjee and Lavie, 2005), BLEURT (Sellam et al., 2020), YiSi (Lo, 2019), ESIM (Mathur et al., 2019), and BEER (Stanojević and Sima'an, 2014). Model-based metrics require significant effort and resources when adapting to a new language or domain, while model-free metrics require only a test set with references.

Mathur et al. (2020) have recently evaluated the utility of popular metrics and recommend the use of either $\mathrm{CHRF}_{1}$ or a model-based metric instead of BLEU. We compare our MACROF $\mathrm{F}_{1}$ and MICROF $\mathrm{M}_{1}$ metrics with BLEU, CHRF ${ }_{1}$, and BLEURT (Sellam et al., 2020). While Mathur et al. (2020) use Pearson's correlation coefficient $(r)$ to quantify the correlation between automatic evaluation metrics and human judgements, we instead use Kendall's rank coefficient $(\tau)$, since $\tau$ is more robust to outliers than $r$ (Croux and Dehon, 2010).

\subsection{Rare Words are Important}

That natural language word types roughly follow a Zipfian distribution is a well known phenomenon (Zipf, 1949; Powers, 1998). The frequent types are mainly so-called "stop words," function words, and other low-information types, while most content words are infrequent types. To counter this natural frequency-based imbalance, statistics such as inverted document frequency (IDF) are commonly used to weigh the input words in applications such as information retrieval (Jones, 1972). In NLG tasks such as MT, where words are the output of a classifier, there has been scant effort to address the imbalance. Doddington (2002) is the only work we know of in which the 'information' of an ngram is used as its weight, such that rare n-grams attain relatively more importance than in BLEU. We abandon this direction for two reasons: Firstly, as noted in that work, large amounts of data are required to estimate $n$-gram statistics. Secondly, unequal weighing is a bias that is best suited to datasets where the weights are derived from, and such biases often do not generalize to other datasets. Therefore, unlike Doddington (2002), we assign equal weights to all $n$-gram classes, and in this work we limit our scope to unigrams only.

While BLEU is a precision-oriented measure, 
METEOR (Banerjee and Lavie, 2005) and CHRF (Popović, 2015) include both precision and recall, similar to our methods. However, neither of these measures try to address the natural imbalance of class distribution. BEER (Stanojević and Sima'an, 2014) and METEOR (Denkowski and Lavie, 2011) make an explicit distinction between function and content words; such a distinction inherently captures frequency differences since function words are often frequent and content words are often infrequent types. However, doing so requires the construction of potentially expensive linguistic resources. This work does not make any explicit distinction and uses naturally occurring type counts to effect a similar result.

\subsection{F-measure as an Evaluation Metric}

F-measure (Rijsbergen, 1979; Chinchor, 1992) is extensively used as an evaluation metric in classification tasks such as part-of-speech tagging, named entity recognition, and sentiment analysis (Derczynski, 2016). Viewing MT as a multi-class classifier is a relatively new paradigm (Gowda and May, 2020), and evaluating MT solely as a multiclass classifier as proposed in this work is not an established practice. However, we find that the $F_{1}$ measure is sometimes used for various analyses when BLEU and others are inadequate: The compare-mt tool (Neubig et al., 2019) supports comparison of MT models based on $F_{1}$ measure of individual types. Gowda and May (2020) use $F_{1}$ of individual types to uncover frequency-based bias in MT models. Sennrich et al. (2016) use corpuslevel unigram $F_{1}$ in addition to BLEU and CHRF, however, corpus-level $F_{1}$ is computed as MICROF 1 . To the best of our knowledge, there is no previous work that clearly formulates the differences between micro- and macro- averages, and justifies the use of $\mathrm{MACROF}_{1}$ for MT evaluation.

\section{Discussion and Conclusion}

We have evaluated NLG in general and MT specifically as a multi-class classifier, and illustrated the differences between micro- and macro- averages using MICROF ${ }_{1}$ and $\mathrm{MACROF}_{1}$ as examples (Section 2). MACROF $F_{1}$ captures semantic adequacy better than MICROF$_{1}$ (Section 3.1). BLEU, being a micro-averaged measure, served well in an era when generating fluent text was at least as difficult as generating adequate text. Since we are now in an era in which fluency is taken for granted and seman- tic adequacy is a key discriminating factor, macroaveraged measures such as $\mathrm{MACROF}_{1}$ are better at judging the generation quality of MT models (Section 3.2). We have found that another popular metric, $\mathrm{CHRF}_{1}$, also performs well on direct assessment, however, being an implicitly micro-averaged measure, it does not perform as well as $\mathrm{MACROF}_{1}$ on downstream CLIR tasks (Section 3.3.1). Unlike BLEURT, which is also adequacy-oriented, $\mathrm{MACROF}_{1}$ is directly interpretable, does not require retuning on expensive human evaluations when changing language or domain, and does not appear to have uncontrollable biases resulting from data effects. It is both easy to understand and to calculate, and is inspectable, enabling fine-grained analysis at the level of individual word types. These attributes make it a useful metric for understanding and addressing the flaws of current models. For instance, we have used $\mathrm{MACROF}_{1}$ to compare supervised and unsupervised NMT models at the same operating point measured in BLEU, and determined that supervised models have better adequacy than the current unsupervised models (Section 4).

Macro-average is a useful technique for addressing the importance of the long tail of language, and MACROF $_{1}$ is our first step in that direction; we anticipate the development of more advanced macroaveraged metrics that take advantage of higherorder and character $n$-grams in the future.

\section{Ethical Consideration}

Since many ML models including NMT are themselves opaque and known to possess data-induced biases (Prates et al., 2019), using opaque and biased evaluation metrics in concurrence makes it even harder to discover and address the flaws in modeling. Hence, we have raised concerns about the opaque nature of the current model-based evaluation metrics, and demonstrated examples displaying unwelcome biases in evaluation. We advocate the use of the $\mathrm{MACROF}_{1}$ metric, as it is easily interpretable and offers the explanation of score as a composition of individual type performances. In addition, MACROF $F_{1}$ treats all types equally, and has no parameters that are directly or indirectly estimated from data sets. Unlike MACROF 1 , MICROF and other implicitly or explicitly micro-averaged metrics assign lower importance to rare concepts and their associated rare types. The use of microaveraged metrics in real world evaluation could lead to marginalization of rare types. 
Failure Modes: The proposed $\mathrm{MACROF}_{1}$ metric is not the best measure of fluency of text. Hence we suggest caution while using $\mathrm{MACROF}_{1}$ to draw fluency related decisions. MACROF ${ }_{1}$ is inherently concerned with words, and assumes the output language is easily segmentable into word tokens. Using $\mathrm{MACROF}_{1}$ to evaluate translation into alphabetical languages such as Thai, Lao, and Khmer, that do not use white space to segment words, requires an effective tokenizer. Absent this the method may be ineffective; we have not tested it on languages beyond those listed in Section B.

Reproducibility: Our implementation of MACROF $_{1}$ and MICROF F $_{1}$ has the same user experience as BLEU as implemented in SACREBLEU; signatures are provided in Section A. In addition, our implementation is computationally efficient, and has the same (minimal) software and hardware requirements as BLEU. All data for MT and NLG human correlation studies is publicly available and documented. Data for reproducing the IR experiments in Section 3.3.2 is also publicly available and documented. The data for reproducing the IR experiments in Section 3.3.1 is only available to participants in the CLSSTS shared task.

Climate Impact: Our proposed metrics are on par with BLEU and such model-free methods, which consume significantly less energy than most modelbased evaluation metrics.

\section{Acknowledgements}

The authors thank Shantanu Agarwal, Joel Barry, and Scott Miller for their help with CLSSTS CLIR experiments, and Daniel Cohen for discussions on IR evaluation methods. This research is based upon work supported by the Office of the Director of $\mathrm{Na}$ tional Intelligence (ODNI), Intelligence Advanced Research Projects Activity (IARPA), via AFRL Contract FA8650-17-C-9116. The views and conclusions contained herein are those of the authors and should not be interpreted as necessarily representing the official policies or endorsements, either expressed or implied, of the ODNI, IARPA, or the U.S. Government. The U.S. Government is authorized to reproduce and distribute reprints for Governmental purposes notwithstanding any copyright annotation thereon.

\section{References}

Mikel Artetxe, Gorka Labaka, Eneko Agirre, and Kyunghyun Cho. 2018. Unsupervised neural machine translation. In 6th International Conference on Learning Representations, ICLR 2018, Vancouver, BC, Canada, April 30 - May 3, 2018, Conference Track Proceedings. OpenReview.net.

Satanjeev Banerjee and Alon Lavie. 2005. METEOR: An automatic metric for MT evaluation with improved correlation with human judgments. In Proceedings of the ACL Workshop on Intrinsic and Extrinsic Evaluation Measures for Machine Translation and/or Summarization, pages 65-72, Ann Arbor, Michigan. Association for Computational Linguistics.

Ondrej Bojar, Christian Buck, Christian Federmann, Barry Haddow, Philipp Koehn, Johannes Leveling, Christof Monz, Pavel Pecina, Matt Post, Herve Saint-Amand, Radu Soricut, Lucia Specia, and Aleš Tamchyna. 2014. Findings of the 2014 workshop on statistical machine translation. In Proceedings of the Ninth Workshop on Statistical Machine Translation, pages 12-58, Baltimore, Maryland, USA. Association for Computational Linguistics.

Ondřej Bojar, Yvette Graham, and Amir Kamran. 2017. Results of the WMT17 metrics shared task. In Proceedings of the Second Conference on Machine Translation, pages 489-513, Copenhagen, Denmark. Association for Computational Linguistics.

Ondřej Bojar, Rajen Chatterjee, Christian Federmann, Yvette Graham, Barry Haddow, Matthias Huck, Antonio Jimeno Yepes, Philipp Koehn, Varvara Logacheva, Christof Monz, Matteo Negri, Aurelie Neveol, Mariana Neves, Martin Popel, Matt Post, Raphael Rubino, Carolina Scarton, Lucia Specia, Marco Turchi, Karin Verspoor, and Marcos Zampieri. 2016. Findings of the 2016 conference on machine translation. In Proceedings of the First Conference on Machine Translation, pages 131-198, Berlin, Germany. Association for Computational Linguistics.

Elizabeth Boschee, Joel Barry, Jayadev Billa, Marjorie Freedman, Thamme Gowda, Constantine Lignos, Chester Palen-Michel, Michael Pust, Banriskhem Kayang Khonglah, Srikanth Madikeri, Jonathan May, and Scott Miller. 2019. SARAL: A low-resource cross-lingual domain-focused information retrieval system for effective rapid document triage. In Proceedings of the 57th Annual Meeting of the Association for Computational Linguistics: System Demonstrations, pages 19-24, Florence, Italy. Association for Computational Linguistics.

Chris Callison-Burch, Cameron Fordyce, Philipp Koehn, Christof Monz, and Josh Schroeder. 2007. (Meta-) evaluation of machine translation. In Proceedings of the Second Workshop on Statistical Machine Translation, pages 136-158, Prague, Czech Republic. Association for Computational Linguistics. 
Nancy Chinchor. 1992. MUC-4 Evaluation Metrics. In Proceedings of the 4th Conference on Message Understanding, MUC4 '92, page 22-29, USA. Association for Computational Linguistics.

Alexis Conneau and Guillaume Lample. 2019. Crosslingual language model pretraining. In $\mathrm{H}$. Wallach, H. Larochelle, A. Beygelzimer, F. d'Alché-Buc, E. Fox, and R. Garnett, editors, Advances in Neural Information Processing Systems 32, pages 70597069. Curran Associates, Inc.

Christophe Croux and Catherine Dehon. 2010. Influence functions of the spearman and kendall correlation measures. Statistical methods \& applications, 19(4):497-515.

Michael Denkowski and Alon Lavie. 2011. Meteor 1.3: Automatic metric for reliable optimization and evaluation of machine translation systems. In Proceedings of the Sixth Workshop on Statistical Machine Translation, pages 85-91, Edinburgh, Scotland. Association for Computational Linguistics.

Leon Derczynski. 2016. Complementarity, F-score, and NLP evaluation. In Proceedings of the Tenth International Conference on Language Resources and Evaluation (LREC'16), pages 261-266, Portorož, Slovenia. European Language Resources Association (ELRA).

George Doddington. 2002. Automatic evaluation of machine translation quality using n-gram cooccurrence statistics. In Proceedings of the Second International Conference on Human Language Technology Research, HLT '02, page 138-145, San Francisco, CA, USA. Morgan Kaufmann Publishers Inc.

Claire Gardent, Anastasia Shimorina, Shashi Narayan, and Laura Perez-Beltrachini. 2017. Creating training corpora for NLG micro-planners. In Proceedings of the 55th Annual Meeting of the Association for Computational Linguistics (Volume 1: Long Papers), pages 179-188. Association for Computational Linguistics.

Jonas Gehring, Michael Auli, David Grangier, Denis Yarats, and Yann N Dauphin. 2017. Convolutional sequence to sequence learning. In Proceedings of the 34th International Conference on Machine Learning-Volume 70, pages 1243-1252.

Thamme Gowda and Jonathan May. 2020. Finding the optimal vocabulary size for neural machine translation. In Findings of the Association for Computational Linguistics: EMNLP 2020, pages 3955-3964, Online. Association for Computational Linguistics.

Gregory Grefenstette. 2012. Cross-language information retrieval, volume 2. Springer Science \& Business Media.

Karen Spärck Jones. 1972. A statistical interpretation of term specificity and its application in retrieval. Journal of Documentation, 28:11-21.
Karen Spärck Jones, Steve Walker, and Stephen E. Robertson. 2000. A probabilistic model of information retrieval: development and comparative experiments: Part 2. Information processing \& management, 36(6):809-840.

Philipp Koehn. 2005. Europarl: A parallel corpus for statistical machine translation. Proc. 10th Machine Translation Summit (MT Summit), 2005, pages 7986.

Guillaume Lample, Alexis Conneau, Ludovic Denoyer, and Marc'Aurelio Ranzato. 2018a. Unsupervised machine translation using monolingual corpora only. In 6th International Conference on Learning Representations, ICLR 2018, Vancouver, BC, Canada, April 30 - May 3, 2018, Conference Track Proceedings. OpenReview.net.

Guillaume Lample, Myle Ott, Alexis Conneau, Ludovic Denoyer, and Marc'Aurelio Ranzato. 2018b. Phrase-based \& neural unsupervised machine translation. In Proceedings of the 2018 Conference on Empirical Methods in Natural Language Processing, pages 5039-5049, Brussels, Belgium. Association for Computational Linguistics.

Constantine Lignos, Daniel Cohen, Yen-Chieh Lien, Pratik Mehta, W. Bruce Croft, and Scott Miller. 2019. The challenges of optimizing machine translation for low resource cross-language information retrieval. In Proceedings of the 2019 Conference on Empirical Methods in Natural Language Processing and the 9th International Joint Conference on Natural Language Processing (EMNLP-IJCNLP), pages 3497-3502, Hong Kong, China. Association for Computational Linguistics.

Yinhan Liu, Jiatao Gu, Naman Goyal, Xian Li, Sergey Edunov, Marjan Ghazvininejad, Mike Lewis, and Luke Zettlemoyer. 2020. Multilingual denoising pre-training for neural machine translation.

Chi-kiu Lo. 2019. YiSi - a unified semantic MT quality evaluation and estimation metric for languages with different levels of available resources. In Proceedings of the Fourth Conference on Machine Translation (Volume 2: Shared Task Papers, Day 1), pages 507-513, Florence, Italy. Association for Computational Linguistics.

Qingsong Ma, Ondřej Bojar, and Yvette Graham. 2018. Results of the WMT18 metrics shared task: Both characters and embeddings achieve good performance. In Proceedings of the Third Conference on Machine Translation: Shared Task Papers, pages 671-688, Belgium, Brussels. Association for Computational Linguistics.

Qingsong Ma, Johnny Wei, Ondřej Bojar, and Yvette Graham. 2019. Results of the WMT19 metrics shared task: Segment-level and strong MT systems pose big challenges. In Proceedings of the Fourth Conference on Machine Translation (Volume 
2: Shared Task Papers, Day 1), pages 62-90, Florence, Italy. Association for Computational Linguistics.

Nitika Mathur, Timothy Baldwin, and Trevor Cohn 2019. Putting evaluation in context: Contextual embeddings improve machine translation evaluation. In Proceedings of the 57th Annual Meeting of the Association for Computational Linguistics, pages 2799-2808, Florence, Italy. Association for Computational Linguistics.

Nitika Mathur, Timothy Baldwin, and Trevor Cohn. 2020. Tangled up in BLEU: Reevaluating the evaluation of automatic machine translation evaluation metrics. In Proceedings of the 58th Annual Meeting of the Association for Computational Linguistics, pages 4984-4997, Online. Association for Computational Linguistics.

Graham Neubig, Zi-Yi Dou, Junjie Hu, Paul Michel, Danish Pruthi, and Xinyi Wang. 2019. compare-mt: A tool for holistic comparison of language generation systems. In Proceedings of the 2019 Conference of the North American Chapter of the Association for Computational Linguistics (Demonstrations), pages 35-41, Minneapolis, Minnesota. Association for Computational Linguistics.

Myle Ott, Sergey Edunov, Alexei Baevski, Angela Fan, Sam Gross, Nathan Ng, David Grangier, and Michael Auli. 2019. fairseq: A fast, extensible toolkit for sequence modeling. In Proceedings of NAACL-HLT 2019: Demonstrations.

Kishore Papineni, Salim Roukos, Todd Ward, and WeiJing Zhu. 2002. Bleu: a method for automatic evaluation of machine translation. In Proceedings of the 40th Annual Meeting of the Association for Computational Linguistics, pages 311-318, Philadelphia, Pennsylvania, USA. Association for Computational Linguistics.

Maja Popović. 2015. chrF: character n-gram f-score for automatic MT evaluation. In Proceedings of the Tenth Workshop on Statistical Machine Translation, pages 392-395, Lisbon, Portugal. Association for Computational Linguistics.

David M. W. Powers. 1998. Applications and explanations of Zipf's law. In New Methods in Language Processing and Computational Natural Language Learning.

Marcelo O.R. Prates, Pedro H. Avelar, and Luís C. Lamb. 2019. Assessing gender bias in machine translation: a case study with google translate. $\mathrm{Neu}$ ral Computing and Applications, pages 1-19.

C. J. Van Rijsbergen. 1979. Information Retrieval, 2nd edition. Butterworth-Heinemann, USA.

Thibault Sellam, Dipanjan Das, and Ankur Parikh. 2020. BLEURT: Learning robust metrics for text generation. In Proceedings of the 58th Annual Meeting of the Association for Computational Linguistics, pages 7881-7892, Online. Association for Computational Linguistics.

Rico Sennrich, Barry Haddow, and Alexandra Birch. 2016. Neural machine translation of rare words with subword units. In Proceedings of the 54th Annual Meeting of the Association for Computational Linguistics (Volume 1: Long Papers), pages 17151725, Berlin, Germany. Association for Computational Linguistics.

Anastasia Shimorina. 2018. Human vs automatic metrics: on the importance of correlation design. CoRR, abs/1805.11474.

Matthew Snover, Bonnie Dorr, Richard Schwartz, Linnea Micciulla, and John Makhoul. 2006. A study of translation edit rate with targeted human annotation. In Proceedings of association for machine translation in the Americas, volume 200. Cambridge, MA.

Kaitao Song, Xu Tan, Tao Qin, Jianfeng Lu, and TieYan Liu. 2019. MASS: Masked sequence to sequence pre-training for language generation. In Proceedings of Machine Learning Research, volume 97, pages 5926-5936, Long Beach, California, USA. PMLR.

Miloš Stanojević and Khalil Sima'an. 2014. BEER: BEtter evaluation as ranking. In Proceedings of the Ninth Workshop on Statistical Machine Translation, pages 414-419, Baltimore, Maryland, USA. Association for Computational Linguistics.

Ashish Vaswani, Noam Shazeer, Niki Parmar, Jakob Uszkoreit, Llion Jones, Aidan N Gomez, Łukasz Kaiser, and Illia Polosukhin. 2017. Attention is all you need. In Advances in neural information processing systems, pages 5998-6008.

William Webber, Alistair Moffat, and Justin Zobel. 2010. A similarity measure for indefinite rankings. ACM Transactions on Information Systems (TOIS), 28(4):1-38.

Steven Wegmann, Arlo Faria, Adam Janin, Korbinian Riedhammer, and Nelson Morgan. 2013. The TAO of ATWV: Probing the mysteries of keyword search performance. In 2013 IEEE Workshop on Automatic Speech Recognition and Understanding, pages 192197. IEEE.

Hans Yang. 2020. XLM-UNMT-Models. https:// github.com/Hansxsourse/XLM- UNMT - Models.

Ilya Zavorin, Aric Bills, Cassian Corey, Michelle Morrison, Audrey Tong, and Richard Tong. 2020. Corpora for cross-language information retrieval in six less-resourced languages. In Proceedings of the workshop on Cross-Language Search and Summarization of Text and Speech (CLSSTS2020), pages 7-13, Marseille, France. European Language Resources Association.

George Kingsley Zipf. 1949. Human behaviour and the principle of least-effort. Cambridge MA edn. Addison-Wesley. 


\section{A Metrics Reproducibility}

BLEU scores reported in this work are computed with the SACREBLEU library and have signature BLEU+case.mixed+lang. $<x x>-<y y>+$ numrefs. 1 +smooth. exp+tok. $<$ TOK >+version.1.4.13, where <TOK> is $z h$ for Chinese, and 13a for all other languages. MACROF $_{1}$ and MICROF $_{1}$ use the same tokenizer as BLEU. CHRF $_{1}$ is also obtained using SACREBLEU and has signature chrFl+lang. $<x x>-<y y>+$ numchars. 6 +space.false +version.1.4.13. BLUERT scores are from the base model of Sellam et al. (2020), which is fine-tuned on WMT Metrics ratings data from 2015-2018. The BLEURT model is retrieved from https://storage.googleapis.com/ bleurt-oss/bleurt-base-128.zip.

MACROF $_{1}$ and MICROF $_{1}$ are computed using our fork of SACREBLEU as: sacrebleu \$REF - m macrof microf < \$HYP.

\section{B Agreement with WMT Human Judgments}

Tables 9,10 , and 11 provide $\tau$ between MT metrics and human judgments on WMT Metrics task 2017 2019. $\star$ BLEU is based on pre-computed scores in WMT metrics package, whereas BLEU is based on our recalculation using SACREBLEU. Values marked with ${ }^{\times}$are not significant at $\alpha=0.05$, and hence corresponding rows are excluded from the calculation of mean, median, and standard deviation.

Since MACROF $_{1}$ is the only metric that does not achieve statistical significance in the WMT 2019 EN-ZH setting, we carefully inspected it. Human scores for this setting are obtained without looking at the references by bilingual speakers ( $\mathrm{Ma}$ et al., 2019), but the $\mathrm{ZH}$ references are found to have a large number of bracketed EN phrases, especially proper nouns that are rare types. When the text inside these brackets is not generated by an MT system, MACROF 1 naturally penalizes heavily due to the poor recall. Since other metrics assign lower importance to poor recall of such rare types, they achieve relatively better correlation to human

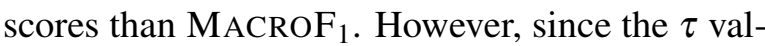
ues for EN-ZH are relatively lower than the other language pairs, we conclude that poor correlation of $\mathrm{MACROF}_{1}$ in $\mathrm{EN}-\mathrm{ZH}$ is due to poor quality references. Some settings did not achieve statistical significance due to a smaller sample set as there were fewer MT systems submitted, e.g. 2017 CSEN.

\begin{tabular}{|c|c|c|c|c|c|}
\hline & $\star$ BLEU & BLEU & MACROF $_{1}$ & MICROF $_{1}$ & $\mathrm{CHRF}_{1}$ \\
\hline DE-CS & .855 & .745 & .964 & .917 & .982 \\
\hline DE-EN & .571 & .655 & .723 & .695 & .742 \\
\hline DE-FR & .782 & .881 & .927 & .844 & .915 \\
\hline EN-CS & .709 & .954 & .927 & .927 & .908 \\
\hline EN-DE & .540 & .752 & .741 & .773 & .824 \\
\hline EN-FI & .879 & .818 & .879 & .848 & .923 \\
\hline EN-GU & .709 & .709 & .600 & .734 & .709 \\
\hline EN-KK & .491 & .527 & .685 & .636 & .661 \\
\hline EN-LT & .879 & .848 & .970 & .939 & .881 \\
\hline EN-RU & .870 & .848 & .939 & .879 & .930 \\
\hline FI-EN & .788 & .809 & .909 & .901 & .875 \\
\hline FR-DE & .822 & .733 & .733 & .764 & .815 \\
\hline GU-EN & .782 & .709 & .855 & .891 & .945 \\
\hline KK-EN & .891 & .844 & .796 & .844 & .881 \\
\hline LT-EN & .818 & .855 & .844 & .855 & .833 \\
\hline RU-EN & .692 & .729 & .714 & .780 & .757 \\
\hline ZH-EN & .695 & .695 & .752 & .676 & .715 \\
\hline Median & .782 & .752 & .844 & .844 & .875 \\
\hline Mean & .751 & .771 & .821 & .818 & .841 \\
\hline SD & .124 & .101 & .112 & .093 & .095 \\
\hline EN-ZH & .606 & .606 & .424 & .595 & .594 \\
\hline Wins & 3 & 3 & 6 & 3 & 5 \\
\hline
\end{tabular}

Table 9: WMT19 Metrics task: Kendall's $\tau$ between metrics and human judgments.

\section{UNMT and SNMT Models}

The UNMT models follow XLM's standard architecture and are trained with 5 million monolingual sentences for each language using a vocabulary size of 60,000 . We train SNMT models for $\mathrm{EN} \leftrightarrow \mathrm{DE}$ and select models with the most similar (or a slightly lower) BLEU as their UNMT counterparts on newstest2019. The DE-EN model selected is trained with 1 million sentences of parallel data and a vocabulary size of 64,000 , and the EN-DE model selected is trained with 250,000 sentences of parallel data and a vocabulary size of 48,000 . For $\mathrm{EN} \leftrightarrow \mathrm{FR}$ and $\mathrm{EN} \leftrightarrow \mathrm{RO}$, we select SNMT models from submitted systems to WMT shared tasks that have similar or slightly lower BLEU scores to corresponding UNMT models, based on NewsTest 2014 for $\mathrm{EN} \leftrightarrow \mathrm{FR}$ and NewsTest2016 for $\mathrm{EN} \leftrightarrow \mathrm{RO}$.

Figure 1, which is a visualization of $\mathrm{MACROF}_{1}$ for SNMT and UNMT models, shows that UNMT is generally better than SNMT on frequent types, however, SNMT outperforms UNMT on the rest leading to a crossover point in $\mathrm{MACROF}_{1}$ curves. Since $\mathrm{MACROF}_{1}$ assigns relatively higher weights to infrequent types than in BLEU, SNMT gains higher $\mathrm{MACROF}_{1}$ than UNMT while both have approximately the same BLEU, as reported in Table 6.

A complete comparison of UNMT vs SNMT in different languages is in Table 12. A manual analysis of the ten sentences with the largest magnitude favoritism according to $\mathrm{MACROF}_{1}$ and BLEU in 


\begin{tabular}{|c|c|c|c|c|c|}
\hline & EU & BL & MAC & $0 \mathrm{~F}$ & HRF \\
\hline DE-EN & .828 & .845 & .917 & .883 & .919 \\
\hline EN-DE & .778 & .750 & .850 & .783 & .848 \\
\hline EN-ET & .868 & .868 & .934 & .906 & .949 \\
\hline EN-FI & .901 & .848 & .901 & .879 & .945 \\
\hline EN-RU & .889 & .889 & .944 & .889 & .930 \\
\hline EN-ZH & .736 & .729 & .685 & .833 & .827 \\
\hline ET-EN & .884 & .900 & .884 & .878 & .904 \\
\hline FI-EN & .944 & .944 & .889 & .915 & .957 \\
\hline RU-EN & .786 & .786 & .929 & .857 & .869 \\
\hline ZH-EN & .824 & .872 & .738 & .780 & .820 \\
\hline EN-CS & 1.000 & 1.000 & .949 & 1.000 & .949 \\
\hline Median & .868 & .868 & .901 & .879 & .919 \\
\hline Mean & .858 & .857 & .875 & .873 & .902 \\
\hline SD & .077 & .080 & .087 & .062 & .052 \\
\hline TR-EN & .200 & $\times .738$ & .400 & .316 & ${ }^{\times} .632$ \\
\hline EN-TR & $\times .571$ & $\times .400$ & .837 & $\times$ ×.571 & .849 \\
\hline CS-EN & $\times .800$ & $\times .800$ & $\times .600$ & $\times .800$ & $\times .738$ \\
\hline
\end{tabular}

Table 10: WMT18 Metrics task: Kendall's $\tau$ between metrics and human judgments.

\begin{tabular}{|c|c|c|c|c|c|}
\hline & $\star B L E U$ & BLEU & MACROF $_{1}$ & MICROF$_{1}$ & $\mathrm{CHRF}_{1}$ \\
\hline DE-EN & .564 & .564 & .734 & .661 & $\overline{.744}$ \\
\hline EN-CS & .758 & .751 & .767 & .758 & .878 \\
\hline EN-DE & .714 & .767 & .562 & .593 & .720 \\
\hline EN-FI & .667 & .697 & .769 & .718 & .782 \\
\hline EN-RU & .556 & .556 & .778 & .648 & 669 \\
\hline EN-ZH & .911 & .911 & .600 & .854 & .899 \\
\hline LV-EN & .905 & .714 & .905 & .905 & .905 \\
\hline RU-EN & .778 & 611 & .611 & .722 & .800 \\
\hline TR-EN & .911 & .778 & .674 & .733 & .907 \\
\hline ZH-EN & .758 & .780 & .736 & .824 & .732 \\
\hline Median & .758 & .733 & .735 & .728 & .791 \\
\hline Mean & .752 & .713 & .714 & .742 & .804 \\
\hline SD & .132 & .110 & .103 & .097 & .088 \\
\hline FI-EN & .867 & .867 & .733 & .867 & .867 \\
\hline EN-TR & .857 & .714 & $\times$ & .643 & .849 \\
\hline CS-EN & $\times 1.000$ & 1.000 & $\times$ ×.667 & $\times .667$ & $\times$ \\
\hline Wins & $J$ & 4 & 2 & 2 & 0 \\
\hline
\end{tabular}

Table 11: WMT17 Metrics task: Kendall's $\tau$ between metrics and human judgments.

\begin{tabular}{lrrl} 
Translation & SNMT & UNMT SNMT Name \\
\hline \hline DE-EN NewsTest2019 & 32.7 & 33.9 Our Transformer \\
EN-DE NewsTest2019 & 24.0 & 24.0 Our Transformer \\
FR-EN NewsTest2014 & 31.1 & 31.2 OnlineA.0 \\
EN-FR NewsTest2014 & 25.6 & 27.1 PROMT-Rule-based.3083 \\
RO-EN NewsTest2016 & 30.8 & 29.6 Online-A.0 \\
EN-RO NewsTest2016 & 31.2 & 31.0 uedin-pbmt.4362
\end{tabular}

Table 12: SNMT systems are selected such that their BLEU scores are approximately the same as the available pretrained UNMT models.

the FR-EN and RO-EN test sets is in Table 13 and Table 14. The complete texts of these sentences, their reference translations, and the system translations (including DE-EN mentioned in Sec 4), are shown in Tables 15, 16, 17, 18, 19, and 20.
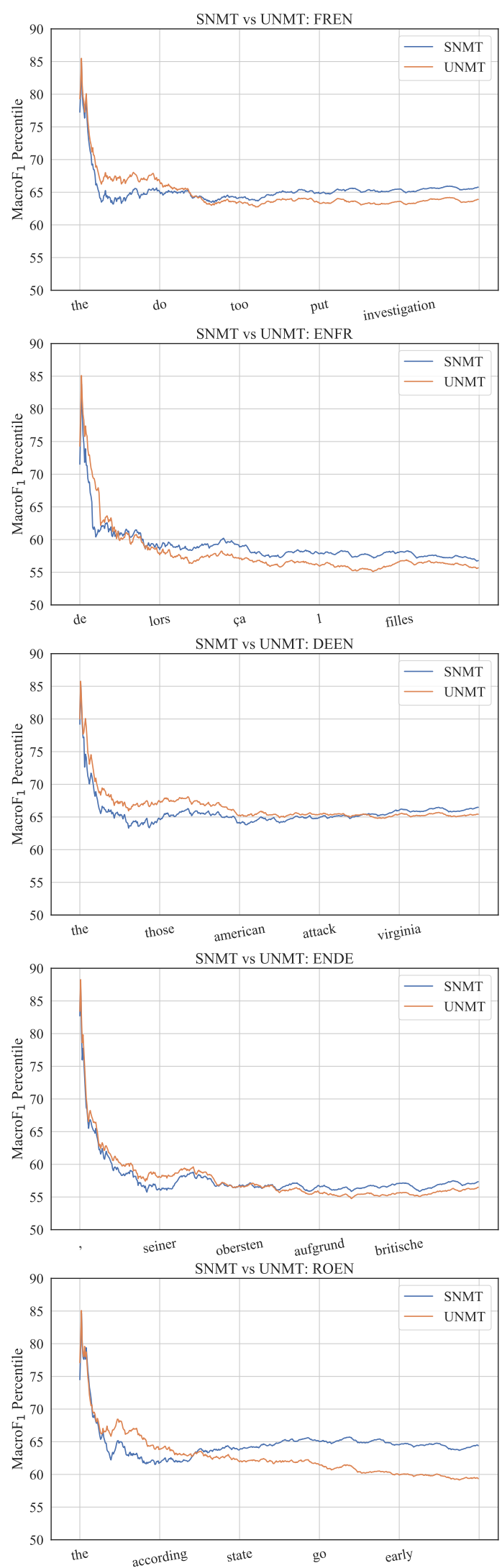

Figure 1: SNMT vs UNMT MACROF ${ }_{1}$ on the most frequent 500 types. UNMT outperforms SNMT on frequent types that are weighed heavily by BLEU however, SNMT is generally better than UNMT on rare types; hence, SNMT has a higher MACROF $\mathrm{M}_{1}$. 


\begin{tabular}{|c|c|c|c|c|c|}
\hline$\delta_{\mathrm{MACROF}_{1}}$ & Fav & Analysis & $\delta_{\text {BLEU }}$ & Fav & Analysis \\
\hline .044 & $\mathrm{~S}$ & S: synonym; U: untranslation, synonym & -.026 & $\mathrm{U}$ & U: synonym; S: omitted adv, word order \\
\hline-.038 & $\mathrm{U}$ & $\mathrm{U}$ : no issues; $\mathrm{S}$ : synonym & .025 & $\mathrm{~S}$ & $\mathrm{~S}$ : no issues; U: determiner, word order \\
\hline .035 & $\mathrm{~S}$ & S: synonym; U: untranslation, synonym & .024 & $\mathrm{~S}$ & $\mathrm{~S}$ : no issues; U: repetition, form \\
\hline-.034 & $\mathrm{U}$ & U: no issues; S: synonym; word_order & .021 & $\mathrm{~S}$ & $\begin{array}{l}\text { S: verb, synonym; U: untranslation, noun, } \\
\text { time, synonym }\end{array}$ \\
\hline-.034 & $\mathrm{U}$ & U: synonym; S: word order, verb_ref & .021 & $\mathrm{~S}$ & S: synonym; U: synonym \\
\hline-.033 & $\mathrm{U}$ & $\mathrm{U}$ : no issues; $\mathrm{S}$ : synonym & -.021 & $\mathrm{U}$ & $\mathrm{U}$ : omitted NER; S: synonym, word order \\
\hline .033 & $S$ & $\begin{array}{l}\text { S: word order; U: untranslation, NER, word } \\
\text { order }\end{array}$ & -.021 & $\mathrm{U}$ & U: untranslation; S: verb, word order \\
\hline .032 & $\mathrm{~S}$ & $\begin{array}{l}\text { S: synonym; U: number, omitted noun, un- } \\
\text { translation, verb }\end{array}$ & -.021 & $\mathrm{U}$ & $\begin{array}{l}\text { U: synonym; S: extra preposition, synonym, } \\
\text { word order }\end{array}$ \\
\hline .030 & S & S: adj; U: untranslation & .021 & $\mathrm{~S}$ & $\mathrm{~S}:$ no issues; $\mathrm{U}: N E R$ \\
\hline .030 & $\mathrm{~S}$ & S: noun, synonym; U: noun, synonym & -.020 & $\mathrm{U}$ & U: synonym; S: synonym, word order \\
\hline
\end{tabular}

Table 13: Analysis of the ten FR-EN test set segments with the most favoritism in SNMT (S) or UNMT (U), according to MACROF 1 (left) and BLEU (right). Fav is the favored system by metrics. Actual examples are shown in Appendix Tables 17 and 18.

\begin{tabular}{|c|c|c|c|c|c|}
\hline$\delta_{\mathrm{MACROF}_{1}}$ & Fav & Analysis & $\delta_{\mathrm{BLEU}}$ & Fav & Analysis \\
\hline .131 & $\overline{\mathrm{S}}$ & S: word order; U: repetition, word order & .114 & $\overline{\mathrm{S}}$ & S: word order; U: repetition, word order \\
\hline .063 & $\mathrm{~S}$ & $\begin{array}{l}\text { S: noun, word order; U: repetition, untrans- } \\
\text { lation, noun }\end{array}$ & .089 & $\mathrm{~S}$ & $\begin{array}{l}\text { S: no issues; U: omitted noun, omitted time, } \\
\text { NER }\end{array}$ \\
\hline .062 & S & $\begin{array}{l}\text { S: extra, untranslation; U: untranslation, } \\
\text { copy }\end{array}$ & -.072 & $\mathrm{U}$ & $\begin{array}{l}\text { U: country, untranslation; S: noun, word } \\
\text { order }\end{array}$ \\
\hline-.052 & $\mathrm{U}$ & $\begin{array}{l}\text { U: untranslation } x 3 \text {, synonym; S: untrans- } \\
\text { lation, synonym }\end{array}$ & -.045 & $\mathrm{U}$ & U: synonym; S: synonym, word order \\
\hline-.052 & $\mathrm{U}$ & $\begin{array}{l}\text { U: untranslation, NER, synonym; S: NER, } \\
\text { synonym }\end{array}$ & -.041 & $\mathrm{U}$ & U: untranslation; S: word order, subject \\
\hline-.052 & $\mathrm{U}$ & U: extra; S: untranslation & -.040 & $\mathrm{U}$ & $\mathrm{U}$ : no issues; $\mathrm{S}$ : number, omitted preposition \\
\hline-.050 & $\mathrm{U}$ & $\mathrm{U}: a d v ; \mathrm{S}:$ incoherent, $a d v$ & .039 & $\mathrm{~S}$ & $\begin{array}{l}\text { S: extra, untranslation; U: untranslation, } \\
\text { copy }\end{array}$ \\
\hline-.050 & $\mathrm{U}$ & $\mathrm{U}$ : active/passive voice, name; $\mathrm{S}$ : name & .036 & $\mathrm{~S}$ & $\mathrm{~S}$ : no issues; U: extra verb \\
\hline-.049 & $\mathrm{U}$ & $\begin{array}{l}\text { U: untranslation; S: untranslation, word or- } \\
\text { der }\end{array}$ & -.035 & $\mathrm{U}$ & $\begin{array}{l}\mathrm{U} \text { : repetition, untranslation, S: verb, syn- } \\
\text { onym, word order }\end{array}$ \\
\hline .048 & $\mathrm{~S}$ & $\mathrm{~S}$ : no issues; $\mathrm{U}: N E R$ & .034 & $\mathrm{~S}$ & S: synonym; U: untranslation \\
\hline
\end{tabular}

Table 14: Analysis of the ten RO-EN test set segments with the most favoritism in SNMT (S) or UNMT (U), according to MACROF 1 (left) and BLEU (right). Fav is the favored system by metrics. Actual examples are shown in Appendix Tables 19 and 20. 
gen, dass sie über eine

leistungsstarke Kanone, eine

Reihe von Flugabwehr- und

Schiffsabwehrraketen sowie

einige Stealth-Technologien

verfügen, wie $z$. B. re-

duzierte Radar-, Infrarot- und akustische Signaturen.

.064 Eine Gruppe maskierter ProSeparatisten, die von der Bereitschaftspolizei zurückgehalten wurden, bewarfen sie mit Eiern und schleuderte Pulverfarbe und erzeugte in den Straßen, die normalerweise von Touristen überfüllt waren, dunkle Staubwolken.
It is understood they will feature a powerful cannon, an array of anti-aircraft and anti-ship missiles as well as some stealth technologies, such as reduced radar, infrared and acoustic signatures.

\section{A group of masked pro-} separatists held back by riot police pelted them with eggs and hurled powder paint, creating dark clouds of dust in streets that would usually be thronged with tourists.
It is assumed that they have a powerful cannon, a series of anti-aircraft and anti-ship missiles, as well as some steam technologies, such as reduced radar, infrared and acoustic signatures.

A group of masked proseparatists held hostage by the riot police brought them to eggs and ignited powder paint and produced dark clouds in the streets that were usually crowded by tourists.

It is understood they have a powerful canon, a number of fluke and ship fire systems and some stealth-controlled technologies, such as reduced radar, infrarot and akustic signposts.

A group of masked proindependence separforces, who were kept away by the Bereitschaftpolice, beheaded them with evocative paint and poured pulverforce paint and created dark Staubations in the streets normally clogged by tourists.

-.055 Il faut bien le faire.

052 In einem Abschnitt gibt es ein Bild eines Schlafsaals, in dem die Studenten auf Kaffeetassen, Vorhänge, Trainer und Bücher klicken, um über die Auswirkungen von Koffein und Licht informiert zu werden und darüber, wie sich die sportliche Leistung durch Schlafmangel und die Bedeutung einer Schlafenszeitroutine beeinflusst.

-.045 Nickelbergbau ist auch in der Provinz wichtig, wird aber hauptsächlich in Morowali betrieben, an der gegenüberliegenden Küste von Sulawesi.

.044 Vor 32 Jahren schloss ich mich als Schüler, wegen der Vernachlässigung der Thatcher-Regierung, Labour an. Diese Vernachlässigung hatte dazu geführt, dass mein Klassenzimmer buchstäblich zusammengebrochen war. Infolgedessen habe ich versucht, mich für bessere öffentliche Dienstleistungen für diejenigen einzusetzen, die sie am meisten brauchen. Egal ob als Gemeinderat oder Minister.

.044 UN-Gesandter Staffan de Mistura hofft, bald die ersten Treffen eines neuen Ausschusses aus Regierungsund Oppositionsmitgliedern einzuberufen, um eine Nachkriegsverfassung für Syrien zu entwerfen und den Weg zu Wahlen zu ebnen.

.043 CBS hatte 3,1 Millionen, NBC 2,94 Millionen, MSNBC 2,89 Millionen und CNN 2,52 Millionen, so Nielsen

-.041 Den Rangers gelangen nur zwei Schüsse in der ersten Hälfte, aber der ehemalige Ibrox-Torhüter Liam Kelly war kaum von Lassana Coulibalys Kopfsprung und dem Treffer eines bisslosen Ovie Ejaria aus der Ruhe zu bringen

.041 Liverpool tritt am MIttwoch um 15.00 Uhr im Stadio San Paolo in Neapel, Italien, gegen Napoli an.
Il faut bien le faire.

In one section there is an image of a dorm room, where students click on coffee cups, curtains, trainers and books to be told about the effects of caffeine and light and how athletic performance is impacted by sleep deficiency, and the importance of a bedtime routine.

Nickel mining is also important in the province, but is mostly concentrated in Morowali, on the opposite coast of Sulawesi.

Ever since I joined Labour 32 years ago as a school pupil, provoked by the Thatcher government's neglect that had left my comprehensive school classroom literally falling down, I've sought to champion better public services for those who need them most whether as a local councillor or government minister.
La gentillesse du personnel II faut bien faire. et la disponibil.

In a section there is an image of a bedroom where students click on coffee cups, curtains, trainers, and books to be informed about the effects of caffeine and light and about how sporting performance is affected by lack of sleep and the importance of sleeping time routine.

Nickelergbau is also important in the province, but is mainly operated in Morewali, on the opposite coas of Sulawesi.

32 years ago, I joined Labour as a student because of the neglect of the Thatcher government, which had led to my classroom literally collapsed, and as a result I tried to promote better public services for those who need it most, whether as a local council or ministers.
In one section, there is a picture of a sleeping sauna where students click on coffee cups, forecourts, coaches and books to be educated about the impact of Koffein and light and about how athletic performance is influenced by sleep loss and the importance of a sleep day routine.

Nickel mining is also important in the province, but is mostly operated in Morowali, on the opposite coast of Sulawesi.

Last 32 years ago, as a student, because of the disdain for the Thatcher-era government, Labour joined Labour.
UN envoy Staffan de Mistura is hoping to soon convene the first meetings of a new committee comprised of government and opposition members to draft a postwar constitution for Syria and pave the way to elections.

CBS had 3.1 million, NBC had 2.94 million, MSNBC had 2.89 million and CNN had 2.52 million, Nielsen said.

Rangers managed just two first-half shots on target but former Ibrox goalkeeper Liam Kelly was barely troubled by Lassana Coulibaly's header and a tame Ovie Ejaria strike.

Liverpool battles Napoli in the group stage of the Champions League at 3 p.m. on Wednesday at Stadio San Paolo in Naples, Italy.
UN envoy Staffan de Mistura hopes to convene soon the first meetings of a new committee of governmen and opposition members to draw up a post-war constitution for Syria and pave the way for elections.

CBS had 3.1 million, NBC 2.94 million, MSNBC 2.89 million and CNN 2.52 million, says Nielsen.

The Ranners only reach two shots in the first half, but the former Ibrox-Torkeeper Liam Kelly was hardly the head of Lassanna Coulibys and the hit of a bissloze Ovi Ejaria.

Liverpool will take place at 3 p.m. at the Stadio San Paolo in Naples, Italy, against Napoli.
U.N. Secretary General Staffan de Mistura hopes to soon join the first meetings of a new committee of government and opposition leaders to design a Nachkriegsrewrite for Syria and clear the path to elections.

CBS had 3.8 million, NBC 3.94 million, MSNBC 3.89 million and CNN 3.52 million, Nielsen said.

The Rangers managed only two shots in the first half but former Ibrox goalkeeper Liam Kelly was unlikely to be helped by Lassana Coulibaly's headfirst tackle and the goal of a bisected Ovie Ejaria.

Liverpool v Napoli at the MItch Stadium at $15.00 \mathrm{pm}$ in Neapel, Italy, on MItch. 


\section{In der letzten Woche wurden mittlere}

Konzentrationen in Küstennähe und auf offener See in Pinellas County gemeldet, geringe bis hohe Konzentrationen auf offener See in Hillsborough County, Hintergrund- bis hohe Konzentrationen in Manatee County, Hintergrund- bis hohe Konzentrationen in Küstennähe und auf offene See in Sarasota County, Hintergrundbis mittlere Konzentrationen in Charlotte County, Hintergrund- bis hohe Konzentrationen in Küstennähe und auf hoher See in Lee County sowie geringe Konzentrationen in Collier County.

.046 Moskau hat wiederholt betont, das die 11-Milliarden-Dollar-Pipeline Nord Stream 2, die die bestehende Pipeline-Kapazität auf 110 Milliarden Kubikmeter verdoppeln soll, ein rein wirtschaftliches Projekt ist.

.044 Der NTS, der für die Betreuung von mehr als 270 historischen Gebäuden, 38 wichtigen Gärten und 76.000 Hektar Land rund um das Land verantwortlich ist, nimmt die Fledermäuse sehr ernst.

.042 George W. Bush telefonierte mit Senatoren, um diese zu überreden, Herrn Kavanaugh zu unterstiutzen, der im Weißen Haus für Herrn Bush gearbeitet hatte und durch ihn seine Frau Ashley traf, die die persönliche Sekretärin von Herrn Bush war.

-.039 Eine Woche nachdem eine offizielle chinesische Zeitung eine vierseitige Anzeige in einer USamerikanischen Tageszeitung auf den gegenseitigen Nutzen des USChina-Handels gestellt hatte, warf der US-amerikanische Botschafter in China Peking vor, die amerikanische Presse zur Verbreitung von Propaganda zu verwenden.

-.037 Sie kümmern sich nicht darum, wen sie verletzen, wen sie überfahren müssen, um Macht und Kontrolle zu bekommen, das ist, was sie wollen, Macht und Kontrolle, wir werden es ihnen nicht geben.

-.034 Mayorga behauptet, Ronaldo se nach dem angeblichen Vorfall auf die Knie gefallen und habe ihr gesagt, er sei „zu 99 Prozent“" ein "guter Kerl“, der von den ,ei "Prozent" im Stich gelassen wurde.

-.032 Palin, 29, aus Wasilla, Alaska, wurde wegen des Verdachts auf häusliche Gewalt verhaftet. Gegen ihn liegt bereits ein Bericht über häusliche Gewalt und Widerstand bei der Festnahme vor, so eine Meldung, die am Samstag von den Alaska State Troopers veröffentlicht wurde.

-.032 "Ich habe [...] nicht versteck Fords Behauptungen, ich habe ihre Geschichte nicht geleakt", erzählte Feinstein dem Komitee, berichtete The Hill.

-.031 Briefings werden immer noch stattfinden, sagte Sanders, aber sollte die Presse die Chance haben, dem Präsidenten der Vereinigten Staaten die Fragen direkt zu stellen, so se das unendlich besser, als mit ihr zu sprechen. offshore of Pinellas County have been reported in the past week, low to high concentrations offshore of Hillsborough County, background to high concentrations in Manatee County, background to high concentrations in or offshore of Sarasota County, background to medium concentrations in Charlotte County, back ground to high concentrations in or offshore of Lee County, and low concentrations in Collier County.

Moscow has repeatedly stressed that the $\$ 11$ billion Nord Stream 2 pipeline, which is set to double the existing pipeline capacity to 110 billion cubic meters, is a purely economic project. The NTS, which is responsible for the care of more than 270 historical buildings, 38 important gardens and 76,000 hectares of land around the country, takes bats very seriously.

George W. Bush has been picking up the phone to call Senators, lobbying them to support Mr Kavanaugh, who worked in the White House for Mr Bush and through him met his wife Ashley, who was Mr Bush's personal secretary.

A week after an official Chinese newspaper ran a fourpage ad in a U.S. daily touting the mutual benefits of U.S.-China trade, the U.S ambassador to China accused Beijing of using the American press to spread propaganda.

They don't care who they hurt, who they have to run over in order to get power and control, that's what they want is power and control, we're not going to give it to them."

Mayorga claims Ronaldo fell to his knees after the alleged incident and told her he was "99 percent" a "good guy" let down by the "one percent."

Palin, 29, of Wasilla, Alaska, was arrested on suspicion of domestic violence, interfering with a report of domesing with a report of domestic violence and resisting arrest, according to a report State Troopers.

"I did not hide Dr. Ford's allegations, I did not leak her story," Feinstein told the committee, The Hill reported.

Briefings will still happen, Sanders said, but "if the press has the chance to ask the president of the United States questions directly, that's infinitely better than talking to me. trations were reported on the coast and open seas in Pinelas County, low to high levels at open sea in Hillsborough County, background to high concentrations in Mantee County, high concentrations in coastal and open seas in Sarsota County, back ground to medium concenrations in Charlotte County, background to high shore and high sea levels in Lee County, and low concentrations in Collier County.

Moscow has repeatedly stressed that the $\$ 11$ billion Nord Stream 2 pipeline, which is supposed to double the existing pipeline capacity 110 billion cubic metres, is a purely economic project. The NTS, which is responsible for the care of more than 270 historic buildings, $38 \mathrm{im}$ portant gardens and 76,000 hectares of land around the country, takes the bats very seriously.

George W. Bush contacted senators to persuade them to support Mr Kavanaugh, who worked in the White House for Mr Bush and met his wife Ashley, who was Mr Bush's personal secretary.

A week after an official Chinese newspaper published a four-page display in a US daily on the mutual benefit of US China trade, the US ambassador to China published in Beijing to use the American press for propaganda.

They do not care about who they hurt whom they mus pass over to gain power and control, that is what they want, power and control, we will not give them.

Mayorga claims that Ronaldo fell to the knees after the alleged incident, saying that he was " $99 \%$ " a" good guy "
left in the lurch by the "one percent".

Palin, 29, from Wasilla, Alaska, was arrested for alleged domestic violence, and a report on domestic violence and opposition to arrest has already been published on Saturday by the Alaska State Trooperator.

'I have [...] not hidden Ford's claims that I have not lived their history," told Finestein the committee, reported The Hill.

briefing is still going to take place, Sanders said, but the press should have the opportunity to put the questions directly to the President of the United States, if that is infinitely better than to talk to her.

moder-

ate to high Konzentrof lead in Küstas County were reported in Pinellas County, low to high Konzentrof lead levels on open water in Hillsborough County, Hintergrundto high levels in Manatee County, Hintergrundto high to high Konzentrin Küstas and on open water in Sarasota County and low Konzentrationen in Charlotte County, Hintergrundto high to high Konzentrin Küstennähe and on open water in Sarasota County.

Moscow has repeatedly
insisted that the 11-billion pipeline, Nord Stream 2, which will double the existing Pipeline-capacity to 110 billion cubic feet, is a purely commercial project.

The NTS, responsible for managing more than 270 historic buildings, 38 key gardens and 74,000 acres of land around the country, said the Fledermäuse are very important.

George W. Bush spoke to senators to help him overture to support Mr. Kavanaugh, who had worked in the White House for Mr. Bush and met through him his wife, Ashley, who was the personal secretary to Mr. Bush.

A week after an official Chinese newspaper published a four-page ad on the mutual benefit of the US-China trade, the U.S. ambassador to China accused Beijing of using the American press to spread propaganda.

They don't care who they hurt, who they have to pass to get power and control, that's 
044 Il ne fallait qu'en déployer les accidents, et l'affaire, jacobinisme oblige, était confiée aux préfets et aux sous-préfets, interprètes autorisés.

038 Les spécialistes disent que les personnes sont systématiquement contraintes à faire leur aveux, malgré un changement dans la loi qui a été voté plus tôt dans l'année interdisant aux autorités de forcer quiconque à s'incriminer lui-même.

.035 Ils sont intersexués, l'intersexualité faisant partie du groupe de la soixantaine de maladies diagnostiquées comme désordres du développement sexuel, un terme générique désignant les personnes possédant des chromosomes ou de gonades (ovaires ou testicules) atypiques ou des organes sexuels anormalement développés.

034 Ces violences sont de plus en plus meurtrières en dépi de mesures de sécurité renforcées et d'opérations militaire d'envergure lancées depuis des mois par le gouvernement de Nouri Al Maliki, dominé par les chiites.

34 Du côté du gouvernement, on estime que 29954 membres des forces armées du président Bachar el-Assad ont trouvé la mort, dont 18678 étaient des combattants des forces progouvernementales et 187 des militants du Hezbollah libanais.

-033 Mercredi, le Centre américain de contrôle et de prévention des maladies a publié une série de directives indiquant comment gére les allergies alimentaires des enfants à l'école.

033 N'est-il pas surprenant de lire dans les colonnes du Monde à quelques semaines d'intervalle d'une part la reproduction de la correspondance diplomatique américaine et d'autre part une condamnation des écoutes du Quai d'Orsay par la NSA ?

032 Les ministères appellent à présent les personnes qui auraient été mordues, griffées, égratignées, ou léchées sur une muqueuse ou sur une peau lésée par ce chaton ou dont l'animal aurait été en contact avec ce chaton entre le 8 et le 28 octobre à contacter le 08.11.00.06.95 entre 10 heures et 18 heures à partir du 1er novembre.

.030 A cette IIIe République, moment central et créateur, Pierre Nora a montré beaucoup d'intérêt et même de tendresse: saluant ceux qui se sont alors employés à réparer la fracture révolutionnaire, en enseignant aux écoliers tout ce qui dans l'ancienne France préparait obscurément la France préprait obss version unifiée de leur histoire.

.030 La théorie dominante sur la façon de traiter les enfants pourvus d'organes sexuels ambigus a été lancée par le Dr John Money, de l'université Johns-Hopkins, qui considérait que le genre est malléable.
All it took was to highlight its mistakes and, in keeping with Jacobinism, the issue would be entrusted to prefects and sub-prefects - the authorised interpreters.

Experts say confessions are still routinely coerced, despite a change in the law earlier this year banning the authorities from forcing anyone to incriminate themselves.

\section{They are intersex, part of a} group of about 60 conditions that fall under the diagnosis of disorders of sexual development, an umbrella term vor those with atypical chromosomes, gonads (ovaries or testes), or unusually developed genitalia.

The violence is becoming more and more deadly in spite of reinforced security measures and large-scale military operations undertaken in recent months by Nouri Al Maliki's government, which is dominated by Shiites.

On the government side, it said 29,954 are members of President Bashar Assad's armed forces, 18,678 are pro-government fighters and 187 are Lebanese Hezbollah militants.

On Wednesday, the Centers for Disease Control and Prevention released a set of guidelines to manage children's food allergies at school.

And is it not surprising to read in the pages of Le Monde, on the one hand, a reproduction of diplomatic correspondence with the US and on the other, condemnation of the NSA's spying on the Ministry of Foreign Affairs on the Quai d'Orsay, within a matter of weeks?

The ministries are currently
asking anyone who might have been bitten, clawed, scratched or licked on a mucous membrane or on damaged skin by the kitten, or who own an animal that may have been in contact with the kitten between 08 to 28 October, to contact them on 081100 0695 between 10am and 6pm from 01 November.

Pierre Nora has shown has shown great interest and even tenderness for this Third Republic: he salutes those who tried at the time to repair the divide created by the Revolution by teaching students about everything in the former France that obscurely paved the way for the modern France, and by offering them a unified version of their history.

The prevailing theory on how to treat children with ambiguous genitalia was put forward by Dr. John Money at Johns Hopkins University, who held that gender was malleable.
It should deploy the accidents, and the case, Jacobinism obliges, was entrusted to the prefects and the sub-prefects, authorized interpreters.

The experts say that people re systematically forced to make their confessions, despite a change in the law which was passed earlier this year prohibiting the authorities to force anyone to incriminating himself.

They are intersex, intersex forming part of the Group of 60 diseases diagnosed as disorders of sexual development, a generic term for people with chromosomes or atypical gonads (ovaries or testes) or abnormally developed sexual organs.

Such violence are more lethal despite measures enhanced security and large-scale military operations launched by the Government of Nouri Al Maliki, the Shia-dominated for months.

On the side of the Govern-

ment, it is estimated that 29 954 members of the armed forces of president Bachar $\mathrm{Al}$ Assad died, whose 18678 were 187 Lebanese Hezbollah militants and fighters of the pro-Government forces.

Wednesday, the US Centre of disease prevention and contro issued a set of guidelines indicating how to manage food allergies of children at the school.

Is it not surprising to rea in the columns of the world a few weeks apart on the one hand the reproduction of American diplomatic correspondence and on the other hand a condemnation of the Quai d'Orsay by the NSA listens?

Departments now call peo-

ple who have been bitten, scratched, scratched or licked on mucous membranes or skin injured by this kitten or where the animal would have been in contact with this kitten be.00 .06 .95 be tween 10 a.m. and 6 p.m. from November 1 .

This third Republic, while central and creator, Pierre Nora has shown great interest and even tenderness: saluting those who then worked to repair the revolutionary divide, by teaching students what in the former France preparing darkly modern France and of fering them a version unified in their history.

The prevailing theory about how to treat children with ambiguous sexual organs was launched by Dr. John Money of the Johns Hopkins University, who considered that the genre is malleable.

It only took to deploy the accidents, and the matter, jacobinite oblige, was handed to the préfets and the sous-préfets, authorized interprètes.

Experts say people are routinely forced to make their confessions, despite a change in the law that was passed earlier in the year banning officials from forcing anyone to incriminate themselves.

They are intersexuzed, with intersexuality making up the group of the soixantaine of diseases diagnosed as disordered sexual development, a generic term dissignant people possessing chromosomes or gonades (ovaries or testicules) atypiques or anormally developed sexual organs.

Those violence is increasingly deadly in the face of increased security measures and major military operations launched for months by Nouri Al Maliki's government, dominated by Shiites.

On the government side, one estimate says 29,954 members of President Bachar alAssad's armed forces have found their way, including 18,678 were fighters from prorovernment forces and 187 from Lebanese Hezbollah mil- 


\begin{tabular}{|c|c|c|c|c|}
\hline$\delta_{\mathrm{BLEU}}$ & Source & Reference & SNMT & UNMT \\
\hline .025 & $\begin{array}{l}\text { Les neuf premiers épisodes de } \\
\text { Sheriff Callie's Wild West seront } \\
\text { disponibles à partir du } 24 \text { novem- } \\
\text { bre sur le site watchdisneyju- } \\
\text { nior.com ou via son application } \\
\text { pour téléphones et tablettes. }\end{array}$ & $\begin{array}{l}\text { The first nine episodes of Sher- } \\
\text { iff Callie's Wild West will } \\
\text { be available from November } \\
24 \text { on the site watchdisneyju- } \\
\text { nior.com or via its application } \\
\text { for mobile phones and tablets. }\end{array}$ & $\begin{array}{l}\text { The first nine episodes of Sher- } \\
\text { iff Callie's Wild West will } \\
\text { be available from November } \\
24 \text { on the site watchdisneyju- } \\
\text { nior.com or via its application } \\
\text { for phones and tablets. }\end{array}$ & $\begin{array}{l}\text { Sheriff first nine episodes of } \\
\text { Sheriff Callie' s Wild West } \\
\text { will be available as of Novem- } \\
\text { ber } 24 \text { on the watchdisneyju- } \\
\text { nior.com website or via its ap- } \\
\text { plication for phones and com- } \\
\text { puters. }\end{array}$ \\
\hline .024 & $\begin{array}{l}\text { Le président Xi Jinping, qui a } \\
\text { pris ses fonctions en mars dernier, } \\
\text { a fait de la lutte contre la cor- } \\
\text { ruption une priorité nationale, es- } \\
\text { timant que le phénomène consti- } \\
\text { tuait une menace à l'existence- } \\
\text { même du Parti communiste. }\end{array}$ & $\begin{array}{l}\text { President Xi Jinping, who } \\
\text { took office last March, has } \\
\text { made the fight against corrup- } \\
\text { tion a national priority, believ- } \\
\text { ing that the phenomenon is a } \\
\text { threat to the very existence of } \\
\text { the Communist Party. }\end{array}$ & $\begin{array}{l}\text { President Xi Jinping, who } \\
\text { took office in March, has } \\
\text { made the fight against corrup- } \\
\text { tion a national priority, be- } \\
\text { lieving that the phenomenon } \\
\text { posed a threat to the very exis- } \\
\text { tence of the Communist Party. }\end{array}$ & $\begin{array}{l}\text { President Xi Jinping, who } \\
\text { took office in March, has } \\
\text { made fighting corruption a na- } \\
\text { tional priority, saying the phe- } \\
\text { nomenon posed a threat to the } \\
\text { Communist Party's existence- } \\
\text { free existence. }\end{array}$ \\
\hline .021 & $\begin{array}{l}\text { Il y a, avec la crémation, "une vi- } \\
\text { olence faite au corps aimé", qui } \\
\text { va être "réduit à un tas de cen- } \\
\text { dres" en très peu de temps, et } \\
\text { non après un processus de décom- } \\
\text { position, qui "accompagnerait les } \\
\text { phases du deuil". }\end{array}$ & $\begin{array}{l}\text { With cremation, there is a } \\
\text { sense of "violence committed } \\
\text { against the body of a loved } \\
\text { one", which will be "reduced } \\
\text { to a pile of ashes" in a very } \\
\text { short time instead of after a } \\
\text { process of decomposition that } \\
\text { "would accompany the stages } \\
\text { of grief". }\end{array}$ & $\begin{array}{l}\text { There, with the cremation, "a } \\
\text { violence made to the beloved } \\
\text { body", which will be "reduced } \\
\text { to a pile of ashes" in a very } \\
\text { short time, and not after a pro- } \\
\text { cess of decomposition, which } \\
\text { "would accompany the phases } \\
\text { of mourning". }\end{array}$ & $\begin{array}{l}\text { There is, with cremation, "vio- } \\
\text { lence done to the loved one," } \\
\text { which is going to be "reduced } \\
\text { to a tas of ashes" in very lit- } \\
\text { tle time, and not after a pro- } \\
\text { cess of disablement, which } \\
\text { would "accompany the phases } \\
\text { of grief." }\end{array}$ \\
\hline-.021 & $\begin{array}{l}\text { Les irréductibles du M23, soit } \\
\text { quelques centaines de combat- } \\
\text { tants, étaient retranchés à près } \\
\text { de } 2000 \text { mètres d'altitude sur } \\
\text { les collines agricoles de Chanzu, } \\
\text { Runyonyi et Mbuzi, proches de } \\
\text { Bunagana et Jomba, deux local- } \\
\text { ités situées à environ } 80 \mathrm{~km} \text { au } \\
\text { nord de Goma, la capitale de la } \\
\text { province du Nord-Kivu. }\end{array}$ & $\begin{array}{l}\text { The diehards of the M23, } \\
\text { who are several hundreds in } \\
\text { number, had entrenched them- } \\
\text { selves at an altitude of almost } \\
2,000 \text { metres in the farmland } \\
\text { hills of Chanzu, Runyonyi } \\
\text { and Mbuzi, close to Buna- } \\
\text { gana and Jomba, two towns } \\
\text { located around } 80 \mathrm{~km} \text { north of } \\
\text { Goma, the capital of North } \\
\text { Kivu province. }\end{array}$ & $\begin{array}{l}\text { The irreducible m } 23 \text {, or a few } \\
\text { hundred fighters, were cut off } \\
\text { to nearly } 2000 \text { metres above } \\
\text { sea level on the hills agricul- } \\
\text { tural Chanzu, Runyonyi and } \\
\text { Mbuzi, near Bunagana and } \\
\text { Jomba, located about } 80 \mathrm{~km} \\
\text { north of Goma, the capital of } \\
\text { the province of North Kivu. }\end{array}$ & $\begin{array}{l}\text { The irréductibles M23, or } \\
\text { some hundred fighters, were } \\
\text { retranchés at nearly } 2000 \text { feet } \\
\text { of altitude on the agricultural } \\
\text { hills of Chanzu, Runyonyi } \\
\text { and Mbuzi, close to Buna- } \\
\text { gana and Jomba, two towns } \\
\text { located about } 80 \text { miles north } \\
\text { of Goma, the capital of North } \\
\text { Kivu province. }\end{array}$ \\
\hline-.021 & $\begin{array}{l}\text { a indiqué que le nouveau tri- } \\
\text { nal des médias « sera toujours } \\
\text { rtial car il s'agit d'un prolonge- } \\
\text { ent du gouvernement » et que } \\
\text { restrictions relatives au con- } \\
\text { lu et à la publicité nuiraient à la } \\
\text { ace du Kenya dans l'économie } \\
\text { ndiale. }\end{array}$ & $\begin{array}{l}\text { He said the new media tri- } \\
\text { bunal "will always be bi- } \\
\text { ased because it's an exten- } \\
\text { sion of the government," and } \\
\text { that restrictions on content } \\
\text { and advertising would damage } \\
\text { Kenya's place in the global } \\
\text { economy. }\end{array}$ & $\begin{array}{l}\text { He said as the new media tri- } \\
\text { bunal will be always par- } \\
\text { tial because it is an exten- } \\
\text { sion of the Government "and } \\
\text { content and advertising restric- } \\
\text { tions hurt instead of the Kenya } \\
\text { into the world economy. }\end{array}$ & $\begin{array}{l}\text { He said the new media tri- } \\
\text { bunal "will always be partial } \\
\text { because it is a extension of } \\
\text { the government" and that re- } \\
\text { strictions relating to content } \\
\text { and advertising would hurt } \\
\text { Kenya's place in the global } \\
\text { economy. }\end{array}$ \\
\hline .021 & $\begin{array}{l}\text { Dans "Les Fous de Benghazi", } \\
\text { il avait été le premier à révéler } \\
\text { l'existence d'un centre de com- } \\
\text { mandement secret de la CIA dans } \\
\text { cette ville, berceau de la révolte } \\
\text { libyenne. }\end{array}$ & $\begin{array}{l}\text { In "Les Fous de Benghazi", he } \\
\text { was the first to reveal the ex- } \\
\text { istence of a secret CIA com- } \\
\text { mand centre in the city, the } \\
\text { cradle of the Libyan revolt. }\end{array}$ & $\begin{array}{l}\text { In "Les Fous de Benghazi", he } \\
\text { was the first to reveal the ex- } \\
\text { istence of a secret CIA com- } \\
\text { mand center in this town, cra- } \\
\text { dle of the Libyan revolt. }\end{array}$ & $\begin{array}{l}\text { In "The Facts of Libya," he } \\
\text { had been the first to reveal the } \\
\text { existence of a secret CIA com- } \\
\text { mand center in that city, the } \\
\text { birthplace of the Libyan upris- } \\
\text { ing. }\end{array}$ \\
\hline - & $\begin{array}{l}\text { Le Sénat américain a approuvé } \\
\text { un projet pilote de } 90 \mathrm{M} \$ 1 \text { l'année } \\
\text { dernière qui aurait porté sur envi- } \\
\text { ron } 10000 \text { voitures. }\end{array}$ & $\begin{array}{l}\text { The U.S. Senate approved a } \\
\$ 90 \text {-million pilot project last } \\
\text { year that would have involved } \\
\text { about } 10,000 \text { cars. }\end{array}$ & $\begin{array}{l}\text { The US Senate has approved } \\
\text { a pilot project of } 90 \mathrm{M} \$ \text { last } \\
\text { year which would have cov- } \\
\text { ered about } 10,000 \text { cars. }\end{array}$ & $\begin{array}{l}\text { The U.S. Senate approved a } \\
\$ 90 \text { million pilot project last } \\
\text { year that would have focused } \\
\text { on about } 10,000 \text { cars. }\end{array}$ \\
\hline
\end{tabular}

Table 18: Top 10 segments by $\left|\delta_{\mathrm{BLEU}}\left(i, h_{S}, h_{U}\right)\right|$ on FR-EN. 
131 David Grimal are o cariera internationala de violonist solo, de-a lungul careia a sustinut regulat concerte în ultimii 20 de ani pe principalele scene de muzica clasica ale lumii și cu orchestre prestigioase cum ar fi Orchestre de Paris, Orchestre Philharmonique de $\mathrm{Ra}$ dio France, Russian National Orchestra, Orchestre National de Lyon, Chamber Orchestra of Europe, Berliner Symphoniker, New Japan Philharmonic Orchestre de l'Opera de Lyon, Mozarteum Orl'Opera de Lyon, Mozarteum Or-
chestra Salzburg, Jerusalem Symphostra Salzburg, Jerusalem Symphony Orchestra și Sinfonia Varso-
via, sub conducerea unor dirivia, sub conducerea unor diribori precum Christoph EschenSchnwandt, Peter Csaba, Heinrich Schiff, Lawrence Foster, Emmanuel Krivine, Mikhail Pletnev, Rafael Fruhbeck de Burgos și Peter Eotvos, Andris Nelsons, Christian Arming.

$063 \mathrm{O}$ parte importantă a magazinului este dedicată raionului uriaş de congelatoare, unde veți găsi frunze de curry, pepene si ghimbir frunze de curry, pepene și ghimbir
congelate, rate întregi, peste, congelate, rate întregi, pește,
sânge și bilă de vită, carcase de sânge și bilă de vită, carcase de
porc, chiftele de peste, cârnați porc, chiftele de pește, cârnați
tradiționali, semi-preparate și multe altele

062 Persoanele interesate vor putea să afle cum să realizeze creații sculpturale florale armonioase (ikebana), cum să surprindă sufletul elementelor înconjurătoare în compozitii plastice folosind arta japoneză a pictării în tus (Sumie) sau cum să îsi exprime propria individualitate si creativita pria univer prin ( moase (grafic, desen, pictura), a
declarat Sorin Mazilu, profesorul declarat Sorin

052 Umorul îmbrățișărilor frecvente ale lui Joey și Chandler, momentele în care se uită la fotbal în fotoliile comode si pasiunea lui Ross pentru Rachel au venit din faptul că se știe că bărbații se pot asocia cu această situatie, chiar dacă adesea se feresc să își exploreze complet sentimentele.

-.052 În plus, zilele următoare vom face receptia lucrărilor de la pasarela care leagă UPU de clinicile de cardiologie, hepatologie și gastroenterologie pentru a asigura transportul în conditii decente a bolnavului din UPƯ în clinicile vecine, a mai explicat managerul unității medicale.

-.052 Desi presa araba anunta ca despartirea lui Sanmartean de Ittihad e iminenta, impresarul antreorului Ladislau Boloni, Arcadie Zaporojanu, spune ca acest lucru nu se va mai intampla.

-05 Cei mai putini sunt cei care au finalizat doctoratul - 0,67 - și tinerii care au terminat liceul ori scoala generala $-6,20 \%$.

-.05 Politica clubului a facut din Viitorul o echipa de urmarit pentru echipele din strainatate, astfel ca Hagi a vandut în aceasta vara de 1,5 milioane de euro - Ianis Hagi (Fiorentina - 1 milion de euro) și Alexandru Mitrita (Bari - $500 \mathrm{mii}$ euro).

$049 \mathrm{Au}$ inclus amestecul de pungași neplătitori de taxe, străini care fraudau telefonic si pseudo non-domi care detin majoritatea non-domi care dețin
ziarelor importante.

048 Constantin Brâncuși se naște la 19 februarie 1876, în Hobita, un mic sat din comuna Peștișani, județul Gorj, la poalele Carpaților.
David Grimal has an international career as a solo violinist. During the last 20 years he held regular concerts on the main classical music stages of the world with prestigious orchestras such as the Orchestre de Paris, Orchestre Philharmonique de Radio France, Russian National Orchestra, Orchestre National de Lyon, Chamber Orchestra of Europe, Berliner Symphoniker, New Japan Philharmonic, Orchestre de l'Opera de Lyon, Salzburg Mozarteum Orchestra, Jerusalem Symphony Orchestra and Sinfonia Varsovia under the direction of conductors such as Christoph Eschenbach, Michel Plasson, Michael Schnwandt, Peter Csaba, Heinrich Schiff, Lawrence Foster, Emmanuel Krivine, Mikhail Pletnev, Rafael Fruhbeck de Burgos and Peter Eotvos, Andris Nelsons, Christian Arming.

A good portion of the store is given over to the massive freezer section, where you'll find frozen curry leaves, bitter melon and galangal, whole ducks, fish, beef blood and bile, pork casings, fish balls, regional sausages, commercially-prepared foods and more.

Those interested will find out how to make harmonious sculptural floral creations (ikebana), how to capture the soul of the surrounding elements in plastic compositions using the Japanese ink painting art (Sumie) or how to express their own individuality and creativity through the muland creativity through the mul列 (graphic, drawing, painting) said
Sorin Mazilu, the teacher of these courses.

The humour of Joey and ChanThe humour of Joey and Chan-
dler's frequent hugs, moments watching football on the comfy chairs, and Ross's pining for Rachel, came from the knowledge that yes, men can all relate to this, even if they often hold back from fully exploring their feelings.

In addition, in the coming days we will accept the works from the bridge linking the ER to the cardiology, hepatology and gas-
troenterology clinics to ensure the troenterology clinics to ensure the proper transfer of patients from the ER to the neighbouring clinics explaine

Although Arab media announced that the separation between Sanmartean and Ittihad is imminent, coach Ladislau Boloni's a ent Arcadia Zaporojanu, says this will no longer happen.

The least numerous are those who
ted the doctorate courses 0.67 - and young people who have finished high school or middle school $-6.20 \%$.

The club's policy made Viitorul a team to be watched by foreign teams, and so Hagi has sold this summer in the amount of $1.5 \mathrm{mil}$ lion Euros - Ianis Hagi (Fiorentina - 1 million euro) and Alexandru Mitrita (Bari - 500 thousand euro).

They included the medley of taxshy rascals, phone-hacking forand pseudo non-doms who own most of our great newspapers.

Constantin Brancusi was born on 19 February 1876 in Hobița, a small village from Peștișani, Gorj ans.
David Grimal has an international career as a solo violinist, along which claimed concerts regularly in the past 20 years in key scene of classical music of the world and with prestigious orchestras such as the Orchestre de Paris, Orchestre Philharmonique de Radio France, Russian National Orchestra, Orchestre National de Lyon, the Chamber Orchestra of Europe, the Berliner Symphoniker, the New Japan Philharmonic. Orchestre de l'Opera de Lyon Orchestre de l'Opera de Lyon The Sozarteum Orchestr the Jerusalem Symphony Orches tra, and Sinfonia Varsovia, under the direction of conductors such as Christoph Eschenbach Michel Plasson, Michael Schnwandt, Peter Csaba, Heinrich Schiff, Lawrence Foster, Emmanuel Krivine, Mikhail Pletne Rafael Fruhbeck de Burgos, an Peter Eotvos, Andris Nelsons, Christian Arming.

An important part of the store is devoted to giant rayon of freezers, where you'll find curry leaves, melon and Ginger frozen leaves, melon and Ginger frozen blood, carcasses of pork, fish balls,
sausages, traditional dishes and more.

Persons interested will be able to earn how to achieve harmonious sculptural floral design (ikebana), how to capture the soul of the surrounding elements in plastic compositions using the Japanese art of painting in India ink (Sumie) or how to express their own individuality and creativity through divicurity (an said Sorin Mazilu, teacher of such courses.

is humor frequently asked îmbrătișărilor of Joey and Chandler, the times when looking at football in comfortable armchairs and Ross's passion for Rache came from the fact that it is known that men may be associated with this case, even if often keep out to explore fully the sentiments.

In addition, the coming days we will make the reception of the works from the footbridge linking the UPU of Cardiology clinics, Hepatology and gastroentero ogy to ensure decent conditions of transportation of the patient from the UPU in neighboring clinics, explained Manager medical unit.

Although the Arabic press announces that the breakup of his impending Sanmartean Ittihad e impresario, Arcadie antreorului Baghery Isaac says that this will no longer happen.

Most are few people who hav ompleted their Ph.d.-0.67-an young people who have completed grade school-high school times $6,20 \%$.

The Club's policy has made the watched for foreign teams, such as Hagi has sold in this summer of 1.5 million euros-lbarr $\mathrm{H}$ (Fiorentina-EUR 1 million) and Alexander Duane (Bari-500 thousand euros).

They included a mixture of tax revenue, pungassi foreign fraudau telephone and non-pseudo domi who hold most major newspapers.

Constantin Brâncuși February 19 was born in 1876, a small Certified village in Peștișani commune, Gorj County, at the foot of the Carpathians.

David Grimal has an international solo violinist, Peter Csaba, Heinrich Schiff, Lawrence Foster, Emmanuel Krivine, Mikhail Pletnev, Mikhail Fruybbeck Orchestra of Burgos and Peter Eotvos, Andris Philharmonique de Radio France, Russian National Orchestra, the French National Orchestra of Lyon, the Berliner Symphoniker, the New Japan Philharmonic, the Orchestre de l'Opera of Lyon, the Mozarteum Orchestra of Lyon, the Jerusalem Symphony Orchestra and Sinfonia of Paris, under the direction 
$\delta_{\mathrm{BLEU}}$ Source

14 David Grimal are o cariera internationala de violonist solo, de-a lungul careia a sustinut regulat concerte în ultimii 20 de ani pe principalele scene de muzica clasica ale lumil si cu orchestre prestigioase cum ar fi
Orchestre de Paris, Orchestre Philharmonique de Radio France, Russian National Orchestra, Orchestre National de Lyon, Chamber Orchestra of Europe, Berliner Symphoniker, New Japan Philharmonic, Orchestre chestra Salzburg, Jerusalem Symphony Orchestra și Sinfonia Varsovia, sub conducerea unor dirijori pre-
cum Christoph Eschenbach, Michel Plasson, Michael Schnwandt, Peter Csaba, Heinrich Schiff, Lawrence Foster, Emmanuel Krivine, Mikhail gos si Peter Eotvos, Andris Nelsons, Christian Arming.

.089 Editia de toamna va avea loc la tombrie), Iasi (Palas, 6-7 octombrie) Brasov tombrie), Cluj Global (Sala Polivalenta, 20-21 octombrie), Cluj IT (Sala Polivalenta, 22-23 octombrie), Sibiu (Centrul de Afaceri, 28-29 octombrie) și Targu-Mures (Teatrul National, 5 noiembrie).

-.072 Realizatorii studiului mai transmit ca "romanii simt nevoie de ceva mai multa aventura în viata lor
$(24 \%)$, urmat de afectiune $(21 \%)$, bani $(21 \%)$, siguranta $(20 \%)$, nou (19\%), sex (19\%), respect $18 \%$, in-
credere $17 \%$, placere $17 \%$, conectare credere $17 \%$, placere $17 \%$, conectare $17 \%$, cunoastere $16 \%$, protectie $14 \%$,
importanta $14 \%$, invatare $12 \%$, liberimportanta $14 \%$, invatare $12 \%$, libertrol 7\%".

-.045 Fed ar trebui să pună problema stabilitătii financiare pe primul loc doar în cazul unei crize majore, cum a fost cutremurul de pe piață din 2008, a declarat Adam S. Posen, fost membru al comisiei de stabilire a
ratei dobânzii din cadrul Bank of ratei dobâ
England.

-.041 Atunci când susținătorilor lui Clinton li se adresează o întrebare deschisă referitor la motivul pentru care ar dori ca ea să câstige cursa, răspunsul
majoritar este că detine experiența majoritar este că deține experiența
adecvată $(16 \%)$, urmat de faptul că
a venit momentul ca o femeie să fie a venit momentul ca o femeie să fie bun candidat pentru această funcție $(10 \%)$

-.040 Clinton este acum sustinută de $47 \%$ din alegătorii democrați (în scădere de la 58\%), în timp ce Sanders este pe locul doi, cu $27 \%$ (în urcare față

să afle cum să realizeze creați sculpturale florale armonioase (ikebana), cum să surprindă sufletul elementelor înconjurătoare în compoziții plastice folosind arta japoneză a pictării în tuș (Sumie)
sau cum să își exprime propria sau cum să își exprime propria
individualitate si creativitate prin universul plurivalent al artelor fruuniversul plurivalent al artelor frudeclarat Sorin Mazilu, profesorul declarat Sorin
acestor cursuri.

.036 Companiile au vacante cateva mi de locuri de munca, oportunitat de internship și stagii de pracdeja anuntate pe site-ul oficial deja anuntate pe site.

-.035 Antrenorul celor de la Brisbane Broncos, Wayne Bennett, a făcut o ușoară referire la Storm după victoria echipei sale în meciul de calificare cu North Queensland Cowboys, jucat sâmbătă seară, când a numit meciul respectiv o ,demonstrație” ligii de rugby si a declarat că cele două echipe din Queensland nu se prea pricep la wrestling.

.034 David Grimal recunoaste ca Les Dissonaces reprezinta "un lux", precizand ca niciunul dintre muzicienii pinde de succesul acestui proiect pentru a trai.
Reference

SNMT

UNMT

-

reer as a solo violinist. During the ast 20 years he held regular conerts on the main classical music stages of the world with prestigiou de Paris, Orchestre Philharmonique de Paris, Orchestre Philharmoniqu Orchestra, Orchestre National de Orchestra, Orchestre National de Berliner Symphoniker, New Japan Philharmonic, Orchestre de l'Opera de Lyon, Salzburg Mozarteum Orchestra, Jerusalem Symphony Orchestra and Sinfonia Varsovia under the direction of conductors such as Christoph Eschenbach, Michel Plasson, Michael Schnwandt, Peter Csaba, Heinrich Schiff, Lawrence Foster, Emmanuel Krivine, Mikhail Pletnev, Rafael Fruhbeck de Burgos and Peter Eotvos,

The autumn edition will take place in Chisinau (Army House 2-3 October), Iasi (Palas 6-7 October), Braso (Army House 14-15 October), Cluj Global (Polyvalent Hall 20-21 October) Cluj IT (Polyvalent Hall 22-23 October), Sibiu (Business Centre 28
29 October) and Targu-Mures (National Theatre, November 5)

The study's conductors transmit that "Romanians feel the need for a little more adventure in their lives (24\%), followed by affection (21\%), money $(21 \%)$, safety $(20 \%)$, new thing $(19 \%)$, sex (19\%) respect $18 \%$, conidence $17 \%$, pleasure $17 \%$, connection $17 \%$, knowledge $16 \%$, protection $14 \%$, importance $14 \%$, learnin $12 \%$, freedom $11 \%$, self-awarenes $10 \%$ and control $7 \%$

The Fed should put financial stability concerns first only during a majo crisis, such as the 2008 market meltdown, said Adam S. Posen, a forme member of the Bank of England's rate-setting committee.

When Clinton's supporters are asked in an open-ended question why the want her to be the nominee, the to answer is that she has the right experience (16 percent), followed by it' time for a woman president ( 13 percent), and that she is the best
date for the job (10 percent).

Clinton now has the backing of 47 percent of Democratic primary voters (down from 58 percent), while Sanders comes in second, with
percent (up from 17 percent). percent (up from 17 percent). to make harmonious sculptural floal creations (ikebana), how to capture the soul of the surrounding elements in plastic compositions using the Japanese ink painting art (Sumie) or how to express their own ind viduality and creativity through the

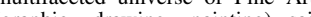
(graphic, drawing, painting) said courses.

Companies have thousands of vacan jobs, internship opportunities and inthem are a www.targuldecariere.ro.

Brisbane Broncos coach Wayne Bennett made a thinly veiled reference (n) Co (whe the rugby league a "showcase" of " he rugby league and said the two wrestling.

David Grimal admits that Les Dissonaces is "a luxury", adding that none of the musicians who are part of the orchestra does not depend on he success of this project to make

SNid has an international ca-

reer as a solo violinist, along which claimed concerts regularly in the past 20 years in key scenes of classical music of the world and with prestigious orchestras such as the Or-
chestre de Paris, Orchestre Philhartional de Lyon, the Chamber Orchestra of Europe, the Berliner Symphoniker, the New Japan Philharmonic, Orchestre de l'Opera de Lyon The Salzburg Mozarteum Orchestra, the Jerusalem Symphony Orchestra, and Sinfonia Varsovia, under the direction of conductors such as Christoph Eschenbach, Michel Plasson, Michael Schnwandt, Peter Csaba, Heinrich Schiff, Lawrence Foster, Emmanuel Krivine, Mikhail Pletnev, Rafael Fruhbeck de Burgos, and Peter Eotvos, Andris Nelsons, Christian Arming.

Autumn edition will take place in ober), Jarmy (Palas, 6-7 October), Brasov (Army House, 14-16 October), Global (Sala Polivalenta, 20-21 October), Cluj (Sala Polivalenta, 2223 October), Sibiu (Business Centre, 28-29 October) and Targu-Mures (National Theatre, November 5).

The filmmakers may study transmitted as "Romanians feel in need of something more adventure in their lives $(24 \%)$, followed by affection $(21 \%)$, money $(21 \%)$, security (20\%), new (19\%), sex (19\%), respect, trust and $18 \% 17 \% 17 \%$ pleasure, $17 \%, 16 \%$, knowledge protection $14 \%, 14 \%, 12 \%$, liberty learning $11 \%$, self-awareness and control $10 \%$ $7 \% "$

The Fed should put the issue of financial stability in the first place only in the event of major crises such as the earthquake in the market since 2008, "said Adam s. Posen, a former member of the Commission for determining the interest
of England.

When Clinton supporters are asked to answer an open question regarding why you want her to win the race, the answer is that majority holds appropriate experience (16\%), followed by the fact that the time has come for a woman to be President (13\%), and hat is the best candidate for this position $(10 \%)$

Clinton is now supported by $47 \%$ of the voters Democrats (down 62\%), $27 \%$ (in relation to climb 17\%).

Persons interested will be able to learn how to achieve harmonious sculptural floral design (ikebana), how to capture the soul of the surrounding elements in plastic compositions using the Japanese art of painting in Incia ink (Sumie) or how to express their own individuality and creativity through the unverse plurivalent of fine arts (paintMazilu, teacher of such courses.

Companies have thousands of vacan jobs, internship opportunities, and inreasy ann and site www.targuldecariere.ro.

The coach of the Brisbane Broncos, Wayne Bennett, made a slight referNorth in the qualifying match with Saturday night, when be played maturday "demonstren he called the league and sid that the two tean from Queensland is not too good at wrestling.

wrestling. sonaces represents "a luxury", stating that none of the musicians who are part of the orchestra does not depend on the success of this project for pend on
living. monique de Radio France, Russian National Orchestra, Orchestre Na-

David Grimal has an international solo violinist, Peter Csaba, Heinrich Schiff, Lawrence Foster, Emmanuel Krivine, chestra of Burgos and Peter Eotvos, Orchestra of Burgos and Peter Eotvos, Andris Philharmonique de Radio France, National Orchestra of Lyon, the Berline Symphoniker, the New Japan PhilharSymphoniker, the New Japan Philhar-
monic, the Orchestre de l'Opera of Lyon, the Mozarteum Orchestra of Lyon, the Jerusalem Symphony Orchestra and Sinfonia of Paris, under the direction of conductor like Orchestra: the National Orchestra, the National Orchestra, the French Chamber Orchestra, the Berliner Symphoniology Orchestra and Sinfonia Sinfonia and Sinfonia Sinfonia Sinfonia, the Orchestra of the Paris Symphony Orchestra, the Russian National Orchestra, the National Orchestra, the National Opera of Europe, the Berliner Symphoniker, the Berliner Sym- 